\title{
Utility of petrophysical and geophysical data to constrain the subsurface structure of the Kitakami plutons, northeast Japan
}

\author{
Shigeo Okuma and Hiroshi Kanaya \\ Geological Survey of Japan, National Institute of Advanced Industrial Science and Technology (AIST), \\ Tsukuba Central 7, Higashi 1-1-1, Tsukuba, Ibaraki 305-8567, Japan
}

(Received December 16, 2004; Revised August 4, 2005; Accepted August 11, 2005)

\begin{abstract}
The Geological Survey of Japan (GSJ), AIST has been systematically measuring physical properties of basement rocks in Japan for more than 30 years and has started to construct a petrophysical database called PBRock 21 (Petrophysical Database of Basement rocks in Japan for the 21st Century, http://www.aist.go.jp/RIODB/ PB-Rock21/). The petrophysical data has been integrated with aeromagnetic data to determine the subsurface structure of the Himekami and Sobanokami plutons, members of the Kitakami plutonic belt, northeast Japan. For the Himekami pluton, the result of apparent magnetization intensity mapping clearly shows zonation within subplutons as well as regional rock type differences between the North (felsic) and South (felsic and mafic complex) sub-plutons. The bottom depths of the pluton were estimated by a successive 3-D magnetic modeling to be 1.7 $\mathrm{km}$ (North sub-pluton) and $1.5 \mathrm{~km}$ below sea level (South sub-pluton), respectively. Magnetic modeling of the Sobanokami pluton, which is partly exposed at the eastern edge of the Ishinomaki Plain, implies that the main part of the pluton extends to the northwest below the surface. Its western edge is cut by the Ishinomaki-wan fault, believed to be the upward extension of the fault plane of the 2003 northern Miyagi earthquake as defined by seismic observations and reflection seismic surveys conducted after the earthquake. Integrated magnetic and gravity modeling suggests that the Kakeyama Formation, a Neogene conglomerate deposited in a half-graben along the Ishinomaki-wan fault during Miocene rifting, contains more granitic fragments toward the south than to the north in the Ishinomaki Plain.
\end{abstract}

Key words: Kitakami pluton, petrophysical data, rock magnetic data, magnetic anomaly, gravity anomaly.

\section{Introduction}

As an example of the use of petrophysical data to interpret geophysical data, we show here a case study conducted in the Kitakami Mountains, northeast Japan (Fig. 1), where the Early Cretaceous Kitakami Granites intrude Paleozoic and Mesozoic sedimentary rocks.

The Geological Survey of Japan (GSJ), AIST has been measuring rock physical data mainly of granitic rocks in Japan under the same laboratory conditions for more than 30 years and has started to construct a petrophysical database called PB-Rock 21 (Petrophysical Database of Basement rocks in Japan for the 21st Century, http://www.aist.go.jp/RIODB/PB-Rock21/; Okuma et al., 2003). Based on 391 measurements (Fig. 1), the Kitakami Granites are the most magnetic (magnetic susceptibility $>0.01 \mathrm{SI}$ ) on average among pre-Tertiary granites which crop out in the Japanese Islands, whereas the intensity of Natural Remanent Magnetization (NRM) is relatively low. Consequently, the Königsberger (Qn) ratio is low $(<0.6)$ and the effects of NRM can be considered negligible when interpreting magnetic anomalies caused by these rocks. In contrast Paleozoic and Mesozoic sedimentary rocks surrounding the Kitakami Granites are almost non-

Copyright (c) The Society of Geomagnetism and Earth, Planetary and Space Sciences (SGEPSS); The Seismological Society of Japan; The Volcanological Society of Japan; The Geodetic Society of Japan; The Japanese Society for Planetary Sciences; TERRAPUB magnetic relative to the magnetic granites. This means it is straightforward to estimate the dimensions of the Kitakami plutons by interpretations of the magnetic anomalies in the area.

The Kitakami Granites are relatively dense (average dry and wet densities $>2.75 \times 10^{3} \mathrm{~kg} / \mathrm{m}^{3}$ ) and roughly equivalent to that of Paleozoic and Mesozoic sedimentary rocks, suggesting that it is not easy to interpret gravity anomalies caused by the granitic rocks, though intensive studies were conducted during the initial stage of gravity surveys for their applications to structural interpretations of the major plutons in the area (e.g. Kano and Research group of Granite plutons, Akita Univ., 1978).

In order to understand subsurface structures in the northwestern and southwestern edges of the Kitakami Mountains, we primarily use magnetic models constrained by the rock property measurements and show results of magnetic interpretations.

\section{Geologic Setting}

The northern Tohoku region is underlain by pre-Tertiary basement rocks of the North and South Kitakami belts and Abukuma belt, which are mainly exposed in the Kitakami and Abukuma mountains on the Pacific coast side (Fig. 2; Oide et al., 1989). The North Kitakami and Abukuma belts comprise the Jurassic accretionary complexes, while the South Kitakami belt is a collided continental block composed mainly of Paleozoic sedimentary rocks deposited in 


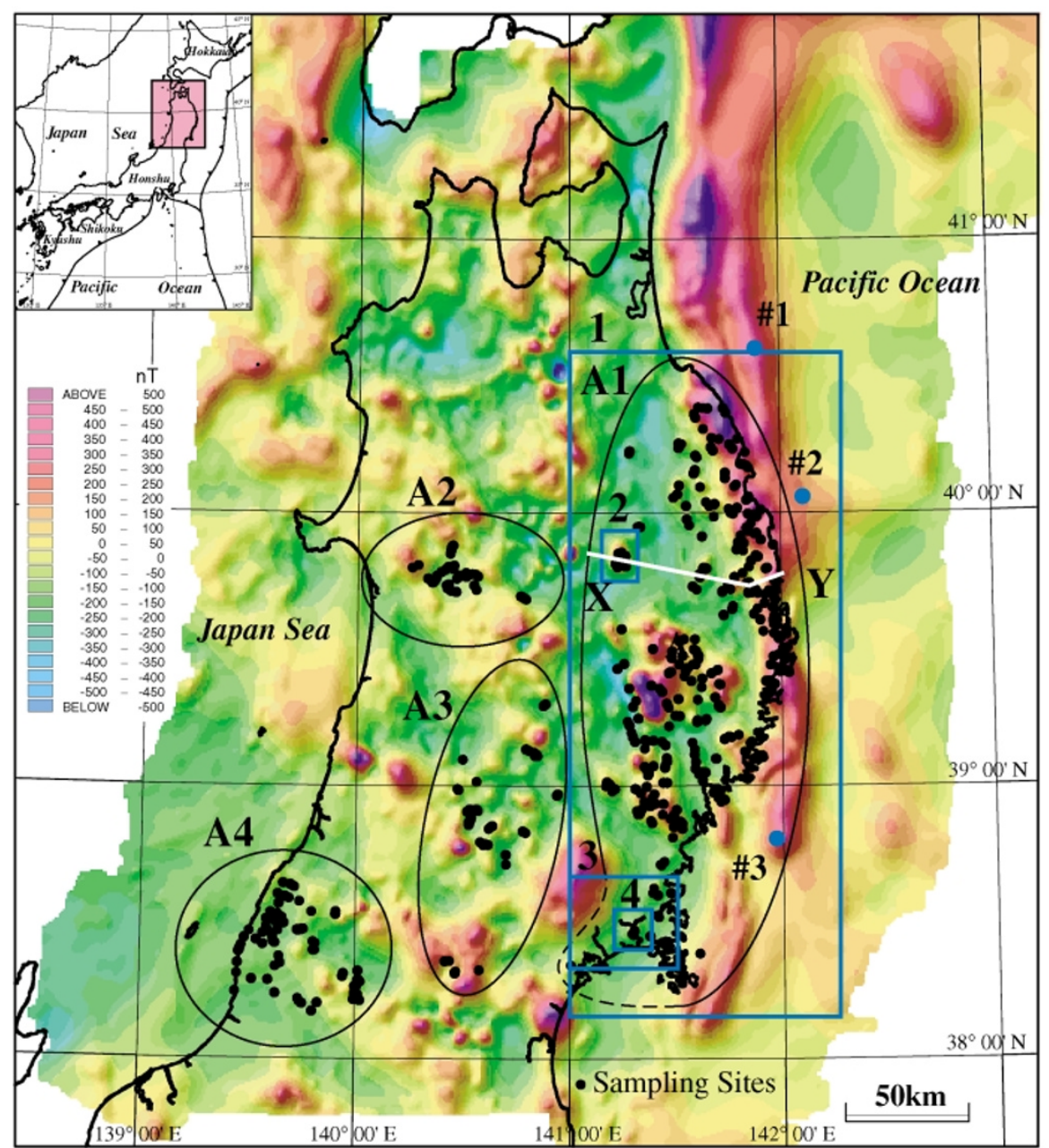

Fig. 1. Location map of the northern Tohoku Area. Color contours are reduction to the pole anomalies (modified from Okuma, 1993). Contour interval is $50 \mathrm{nT}$. Specification of the original aeromagnetic survey by NEDO is summarized in Table 1. Black dots are rock sampling sites. The area bounded by black solid/broken lines indicates rock sampling areas for the petrophysical database, PB-Rock 21: A1; Kitakami Mountains area, A2; Taiheizan area, A3; Kurikoma-Narugo area, A4; Murakami area. The rectangles bounded by blue solid lines show case study areas for magnetic modeling: 1; Kitakami Mountains area, 2; Himekami Area, 3; 2003 northern Miyagi earthquake area, 4; Sobanokami pluton area. The white line with X and Y shows the location of a magnetic profile (Fig. 10). Blue dots are oil exploration wells: \#1; Off-Hachinohe well, \#2; Off-Kuji well, \#3; Off-Kesennuma well.

Table 1. Aeromagnetic anomaly data employed for the magnetic analyses.

\begin{tabular}{lllccl}
\hline Survey Area & Organization & $\begin{array}{c}\text { Survey } \\
\text { Year }\end{array}$ & $\begin{array}{c}\text { Reduced Surface } \\
(\mathrm{mASL})\end{array}$ & $\begin{array}{c}\text { Line Spacing } \\
(\mathrm{km})\end{array}$ & Reference \\
\hline $\begin{array}{l}\text { Tohoku } \\
\begin{array}{l}\text { Sengan } \\
\text { (Hachimantai) }\end{array}\end{array}$ & MEDO $^{* 1}$ & $1981-1982$ & 2,438 & 3 & Okuma (1993) \\
Abukuma & GSJ $^{* 3}$ & 1978 & 1800 & $1-2$ & Okuma and Suto (1987) \\
\hline
\end{tabular}

*1 NEDO: New Energy and Industrial Technology Development Organization.

*2 MITI: Ministry of Industrial Science and Technology.

*3 GSJ: Geological Survey of Japan.

a shallow marine environment. These geologic belts are believed to have been formed along the Asian continental margin by the end of the Jurassic period and successive intensive volcanic activity occurred by the oblique subduction of the Izanagi Plate (Maruyama and Seno, 1986).

Plutonic rocks intruded in the North and South Kitakami belts in Early Cretaceous between 110 and $120 \mathrm{Ma}$ and formed Cretaceous volcano-plutonic complexes in some parts (Kanisawa, 1974). The Abukuma belt was also intruded by plutonic rocks during the period from 90 to 100 Ma. The Kitakami Granites represent these plutonic rocks and are composed of more than 50 named plutons, which are classified into six zones (Zone I $\sim \mathrm{VI}$ ) based on their mode of occurrence, megascopic features and petrography (Katada, 1974; Fig. 3).

The Japan Sea opened in the early and middle Miocene 


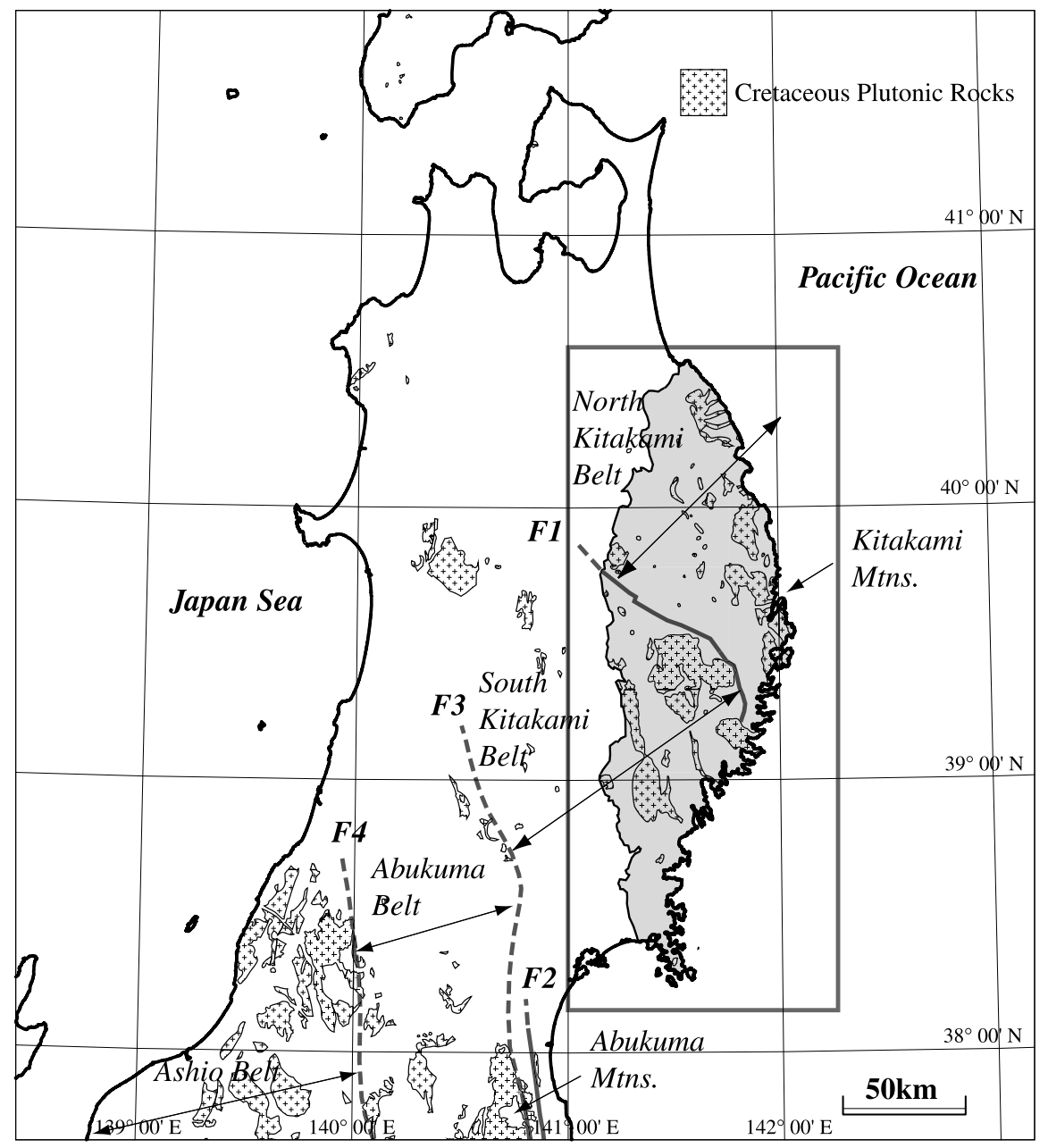

Fig. 2. Simplified geologic map of the northern Tohoku Area (modified from Geological Survey of Japan, 1995). Cretaceous plutonic rocks are shown with major fault lines, F1; Hayachine eastern boundary fault, F2; Futaba fault, F3; Hatakawa shear zone, F4; Tanakura fracture zone (after Oide et al. 1989). The rectangle indicates the area of a detailed map of the Kitakami plutons (Fig. 3).

between 25 and 15 Ma (Jolivet et al., 1994), causing a drift of northern Japan away from the Asian continental margin to roughly its present location.

\section{Petrophysical Database and Characteristics of Petrophysical Data in the Northern Tohoku Re- gion}

We have been measuring petrophysical properties of basement rocks such as granitic and metamorphic rocks in Japan to better understand the geological and geophysical structures of the Japanese Islands (Kanaya, 1974; Kanaya et al., 1998; Okuma and Kanaya, 1990; Okuma et al., 1993; Tanaka and Kanaya, 1986, 1987). Based on the data, we have initiated development of a petrophysical database, called PB-Rock 21 and included the data of basement rocks from the northern Tohoku region in 2003. We will successively add more data from other areas to cover the whole Japanese Islands in several years. The database itself consists of petrophysical data such as magnetic susceptibility, intensity of NRM, Qn ratio, dry and wet densities and porosity with additional information on lithology, sampling locations and registration numbers of rock samples at the Geological Museum of the GSJ. Limited measurements of Curie temperature and ultrasonic velocity are also available.
The uniformity of measurement practices insures repeatability.

Kanaya and Okuma (2003) have examined the petrophysical characteristics of granitic rocks from the northern Tohoku region (Fig. 1) and discussed the general characteristics of the data among four sub-divided areas: the Kitakami Mountains, Taiheizan, Kurikoma-Narugo and Murakami areas. The mean dry density of the four areas varies from 2.66 to $2.77 \times 10^{3} \mathrm{~kg} / \mathrm{m}^{3}$ with the highest values in the Kitakami Mountains (Fig. 4(b)). As for the mean magnetic susceptibility, the Kitakami Mountains is also highest among the areas (Fig. 4(a)). The Qn ratio of more than 70 percent of granitic rocks is less than 0.4 in this region, implying that NRM is negligible when analyzing magnetic anomalies.

Comparing dry and wet densities and magnetic susceptibility of the rocks among the Kitakami Mountains, the values of Zone IV are the highest among the six zones (Fig. 5), suggesting a quantitative difference of mafic rocks among the zones (Oide et al., 1989).

\section{Characteristics of Geophysical Data in the Ki- takami Mountains}

The GSJ conducted regional gravity surveys in the northern Tohoku region in the 1990's and published a gravity 


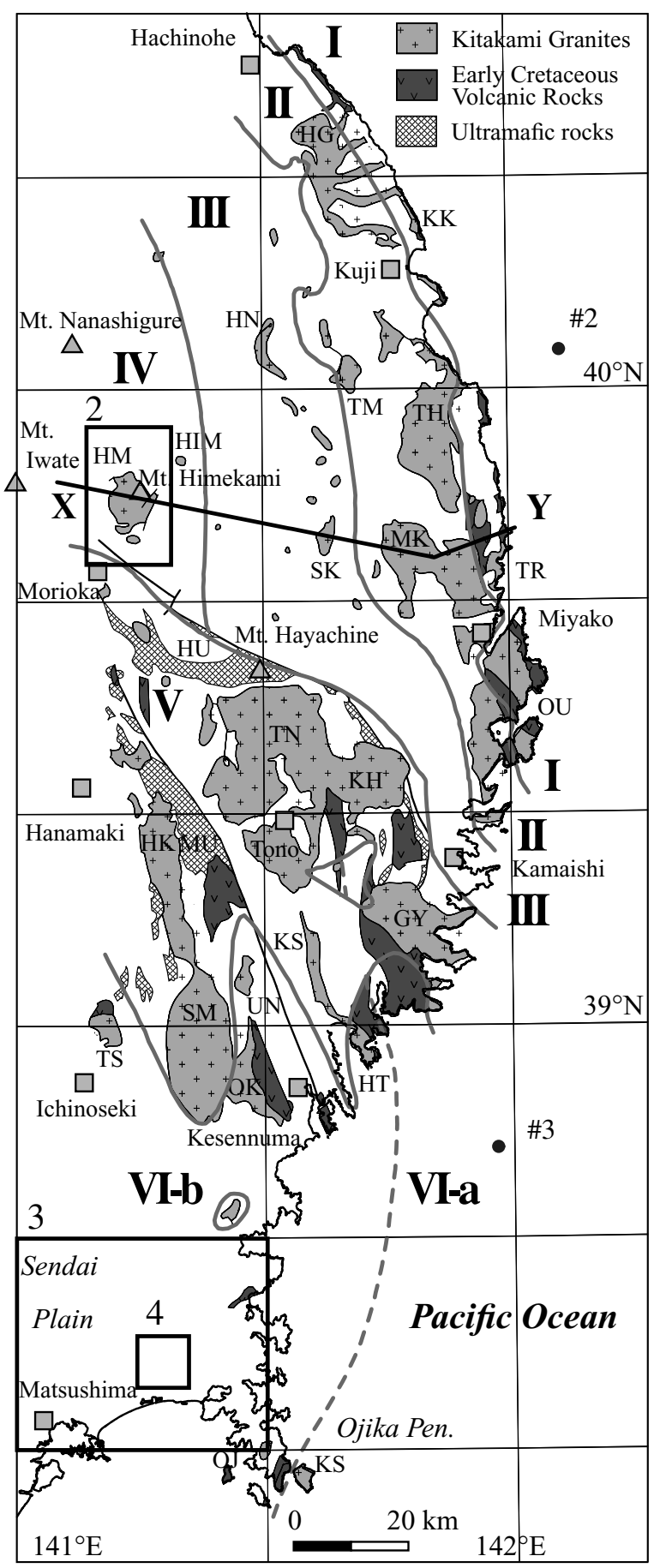

Fig. 3. Zonal arrangements of the Kitakami Granites (after Katada, 1974). I $\sim \mathrm{VI}(\mathrm{a} / \mathrm{b})$ indicate zone numbers. Thick solid lines indicate the boundaries of each zone. Kitakami Granites and ultramafic rocks are plotted with abbreviations for the names of each pluton. Kitakami plutons: KK; Kuki, TR; Taro, OU; Oura (Zone I), HG; Hashigami, TM; Tenjinmori, TH; Tanohata, MK; Miyako (Zone II), HN; Hiraniwa, SK; Sakainokami-dake (Zone III), HIM; Hinomiko, HM; Himekami (Zone IV), TN; Tono, KH; Kurihashi, KS; Kesengawa, GY; Goyosan, HK; Hitokabe, SM: Senmaya (Zone V), KS; Kinkazan (Zone VIa), TS; Tabashine, UN; Uchino, OK; Orikabe, HT: Hirota (Zone VIb). Ultramafic Rocks: HU; Hayachine Ultramafic Rocks, MU; Miyamori Ultramafic Rocks. \#2 and \#3 show the locations of oil exploration wells, Off-Kuji and Off-Kesennuma. Grey rectangles and triangles with names denote locations of major towns and mountains, respectively. (a)

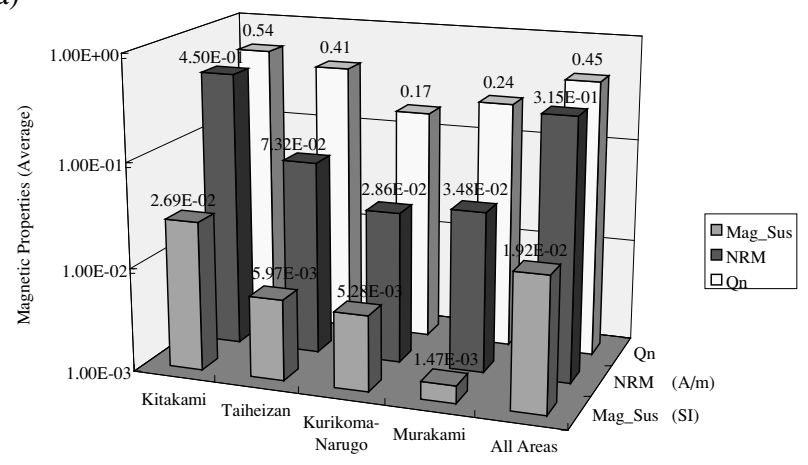

(b) Densities of the Granites in the Northern Tohoku Region

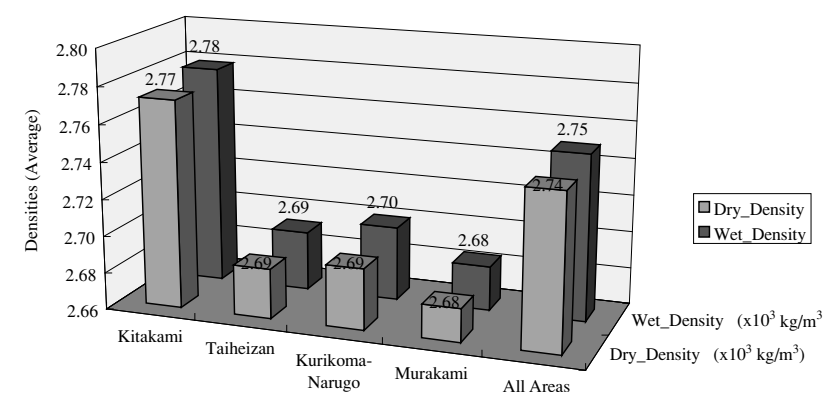

Fig. 4. Petrophysical properties of granitic rocks in the northern Tohoku region. (a) Magnetic properties of granitic rocks in the northern Tohoku region. Mag_Sus: Mean magnetic susceptibility (SI), NRM: Mean intensity of Natural Remanent Magnetization (A/m), Qn: Mean Königsberger ratio. The data with Qn ratio greater than 5.0 (18 data) were excluded for averaging. The numbers of rock samples (numbers in parentheses are original number of samples): Kitakami; 373 (391), Taiheizan; 46 (46), Kurikoma-Narugo; 53 (53), Murakami; 86 (86). (b) Densities of granitic rocks in the northern Tohoku region. Dry_Density: Mean dry density $\left(\times 10^{3} \mathrm{~kg} / \mathrm{m}^{3}\right)$, Wet_Density: Mean wet density $\left(\times 10^{3}\right.$ $\mathrm{kg} / \mathrm{m}^{3}$ ). See also Fig. 4(a).

map of the Kitakami district (Bouguer anomalies) (Komazawa et al., 1996) as well as adjacent areas. Furthermore, Komazawa (2000) compiled a nationwide gravity map based on these surveys including other agency's data and disclosed gravity data in a CD-ROM. According to a Bouguer gravity map $\left(\rho=2.67 \times 10^{3} \mathrm{~kg} / \mathrm{m}^{3}\right)$ of the Kitakami Mountains (Fig. 6), the correlation between the distribution of the Kitakami Granites and gravity signatures is not obvious. This is supported by the fact that the average density of the Kitakami Granites and surrounding Paleozoic and Early Mesozoic mudstones and sandstones are almost the same (Tanaka and Kanaya, 1986, 1987). An exception is the Tono pluton, the largest in the Kitakami Mountains: an obvious oval gravity low is associated with the pluton. Nabetani et al. (1972) analyzed the gravity anomalies over the pluton and estimated a depth extent of $10-15 \mathrm{~km}$ below the surface with density decreasing toward the center of the body. This hypothesis for the density distribution is confirmed by the petrophysical data (Nabetani et al., 1972; Tanaka and Kanaya, 1987; Fig. 6).

Aeromagnetic surveys have been conducted in the study area and the specifications of data employed in this paper 
(a)

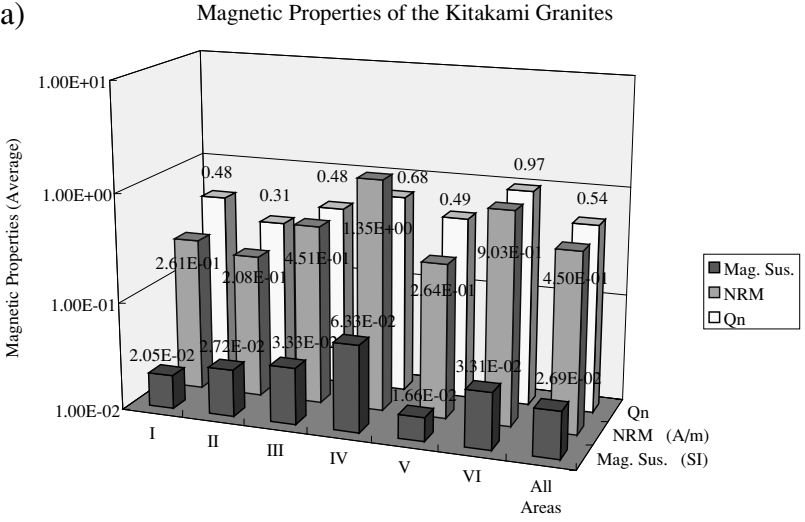

(b)

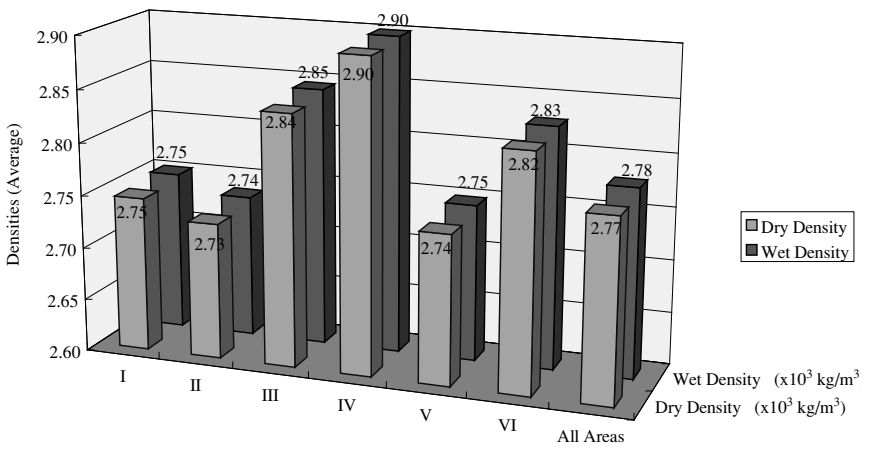

Fig. 5. Petrophysical properties of the Kitakami Granites. (a) Magnetic properties of the Kitakami Granites. I-VI are zone numbers. The numbers of rock samples (numbers in parentheses are original number of samples): I; 50 (54), II; 81 (82), III; 34 (35), IV; 26 (26), V; 120 (129), VI; 62 (65). See also Fig. 4(a). (b) Densities of the Kitakami Granites. See also Figs. 4(b) and 5(a).

are summarized in Table 1. Aeromagnetic anomalies in the Kitakami Mountains are well correlated to the distribution of the Kitakami Granites and most of the plutons can be recognized as magnetic highs (e.g. Okuma, 1993; Fig. 7).

\section{Magnetic Modeling}

\subsection{Himekami pluton}

Magnetic models were constructed for several plutons. The Himekami pluton which crops out about $20 \mathrm{~km}$ northnortheast of Morioka City, Iwate Pref. (Fig. 3) is a complex of mafic rocks and their differentiated felsic counterparts and the main pluton is divided into two sub-plutons: the South and North plutons (Katada et al., 1991). The North pluton (A and B in Fig. 8(a)) is composed mainly of felsic rocks, whereas the South pluton (C in Fig. 8(a)) is composed of both mafic and felsic rocks. The North pluton is divided further into three bodies (Katada et al., 1991) but roughly classified into two parts (A and B in Fig. 8(a)) by the contents of $\mathrm{SiO}_{2}$ and rock magnetic data that are described later.

A long-wavelength dipolar magnetic anomaly indicating a magnetization vector in the Earth's magnetic field lies over the pluton. Within this anomaly is a shortwavelength dipolar magnetic anomaly with the opposite polarity, indicating the heterogeneity of the Himekami Gran-

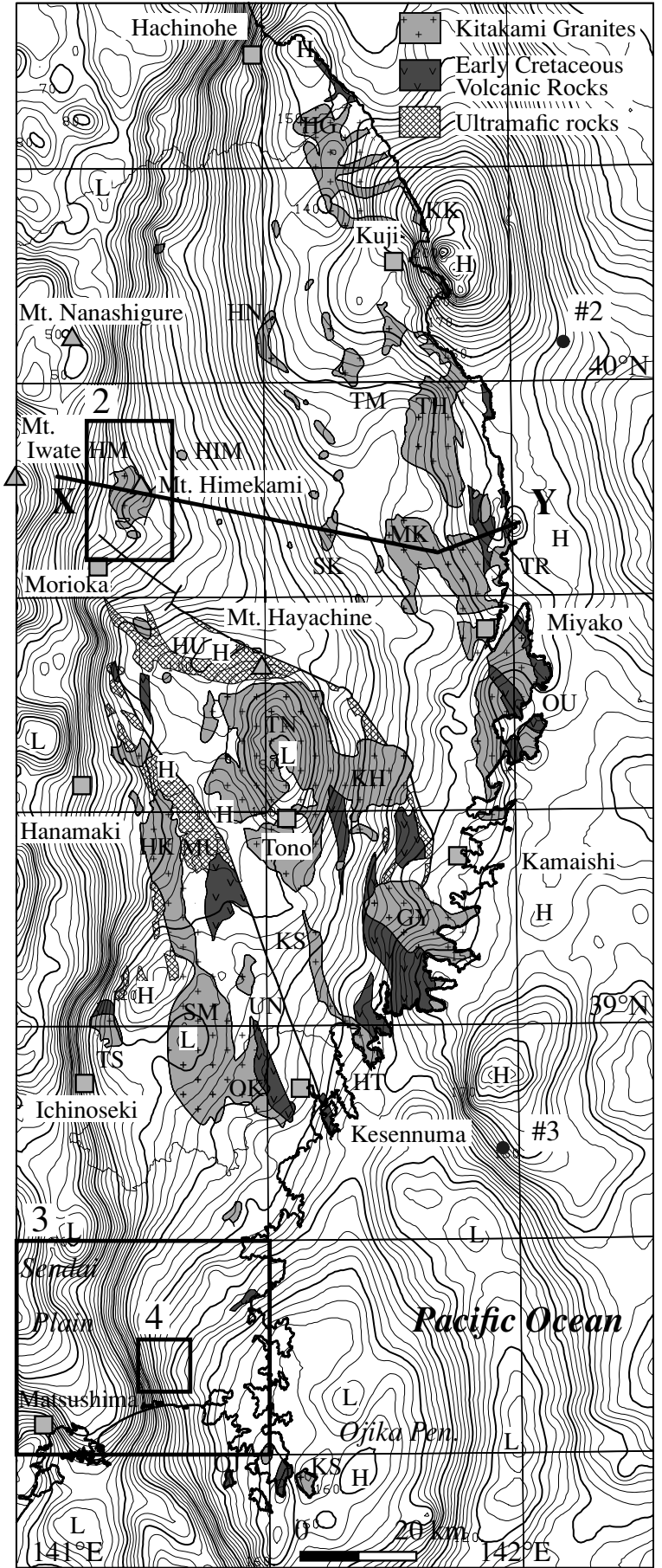

Fig. 6. Bouguer gravity map of the Kitakami Mountains area (after Komazawa, 2000). Assumed Bouguer density: $2.67 \times 10^{3} \mathrm{~kg} / \mathrm{m}^{3}$. Contour interval is $1 \mathrm{mgal}$. $\mathrm{H}$ and $\mathrm{L}$ denote high and low anomalies, respectively. The rectangles 2 and 4 denote magnetic modeling areas; Himekami and Sobanokami plutons, respectively. A thick solid line with $\mathrm{X}$ and $\mathrm{Y}$ shows the location of a magnetic profile (Fig. 10). See also Fig. 3.

ites (Fig. 8(b)). Apparent magnetization mapping (Okuma et al., 1994; Nakatsuka, 1995) was conducted assuming the top and bottom extents of the magnetic structure correspond to the terrain surface and $16 \mathrm{~km}$ below sea level, respectively on the basis of a magnetic model which corresponds to the buried Kitakami plutons along the Pacific coastline of northern Tohoku (Finn, 1994). The resultant apparent mag- 


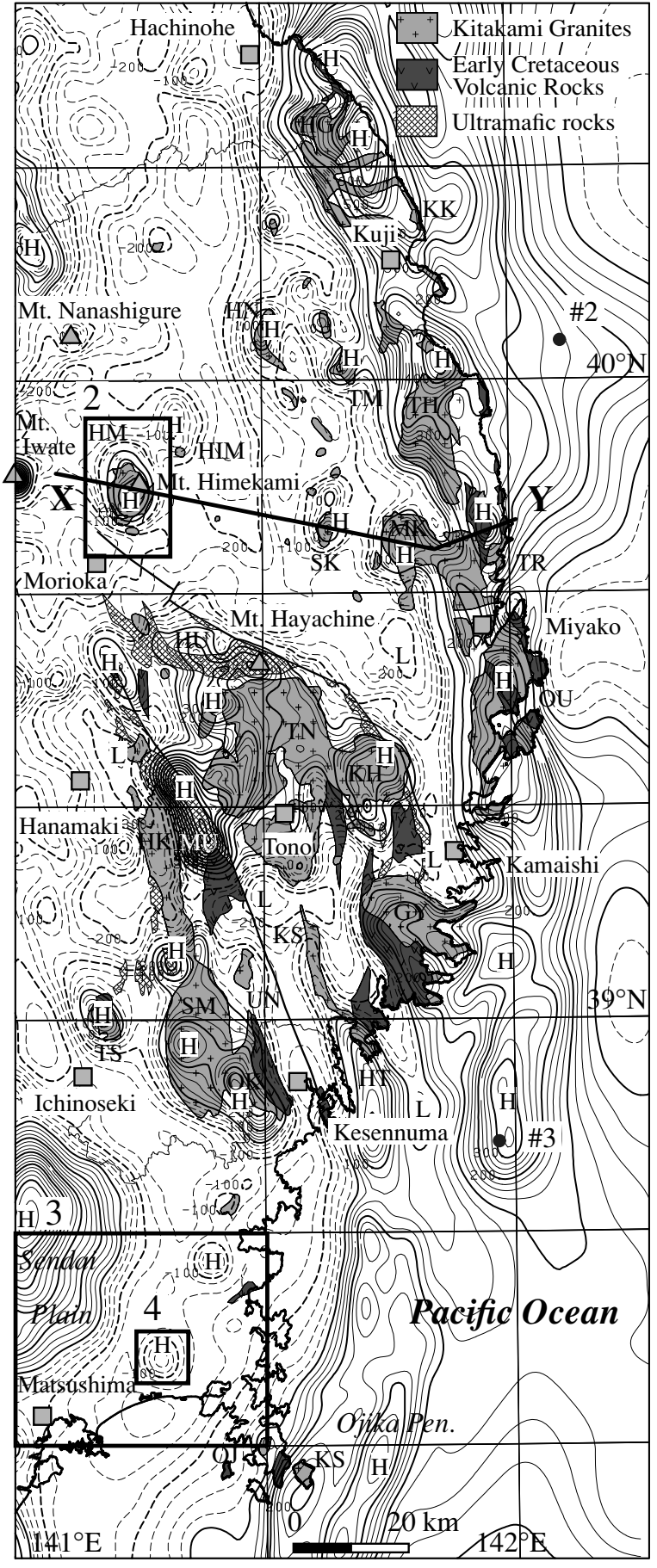

Fig. 7. Reduction to the pole anomaly map of the Kitakami Mountains area (after Okuma, 1993). Contour interval is $25 \mathrm{nT}$. Solid and broken contours indicate positive and negative values, respectively. $\mathrm{H}$ and $\mathrm{L}$ denote high and low anomalies, respectively. See also Fig. 6.

netization intensity map (Fig. 8(c)) clearly shows the magnetization highs lie over the Himekami pluton and anomalies are caused by the pluton. The map also shows a big difference in magnetic properties between the North and South plutons. The calculated magnetization intensities of the South pluton reach $3.0 \mathrm{~A} / \mathrm{m}\left(\kappa=8.0 \times 10^{-2} \mathrm{SI}\right.$, when $F=47,500 \mathrm{nT})$ in some parts with the mean value of 1.24 $\mathrm{A} / \mathrm{m}\left(\kappa=3.28 \times 10^{-2} \mathrm{SI}\right)$, whereas those of the North pluton range from 0.25 to $1.0 \mathrm{~A} / \mathrm{m}\left(\kappa=0.66-2.65 \times 10^{-2}\right.$ SI). Furthermore, the North pluton can be classified into two parts: $\mathrm{A}$ and $\mathrm{B}$ show the mean values of $0.38 \mathrm{~A} / \mathrm{m}$ $\left(\kappa=1.01 \times 10^{-2} \mathrm{SI}\right)$ and $0.74 \mathrm{~A} / \mathrm{m}\left(\kappa=1.96 \times 10^{-2}\right.$ SI), respectively.

The general characteristics of the apparent magnetization intensity mapping correspond well to the measured rock magnetic properties of the pluton (Table 2) and are closely associated with petrography. The North pluton is a zoned pluton of quartz monzonite $\left(\mathrm{SiO}_{2}\right.$ content: $\left.60-65 \%\right)$, granite (63-65\%) and granodiorite (67-70\%) (Katada et al., 1991). The most felsic part of the North pluton, A, is composed of granodiorite and shows the lowest magnetic susceptibility of $1.72 \times 10^{-2}$ SI. Whereas, B comprises quartz monzonite and granite, with a moderate magnetic susceptibility of $4.79 \times 10^{-2} \mathrm{SI}$. The South pluton, C is comprised mainly of quartz monzonite $\left(\mathrm{SiO}_{2}\right.$ content: $\left.55-58 \%\right)$ and quartz monzodiorite (52-54\%) as felsic rocks (Katada et al., 1991), showing the largest magnetic susceptibility of $9.43 \times 10^{-2}$ SI which is almost double that from B and five times greater than that of $\mathrm{A}$. The South pluton is further divided into western and eastern parts based on the hornblende content, and the eastern part contains some mafic rocks such as monzogabbro $\left(\mathrm{SiO}_{2}\right.$ content: $\left.49 \%\right)$ (Katada et al., 1991). The highest magnetic susceptibility of $\mathrm{C}$ was measured on specimens sampled from gabbroic outcrops in the study area. There is an obvious difference in apparent magnetization intensity between the western and eastern parts of area $\mathrm{C}$ : the western part is less magnetic $(<1.0$ $\left.\mathrm{A} / \mathrm{m}\left(\kappa=2.65 \times 10^{-2} \mathrm{SI}\right)\right)$ and the central - eastern part is more magnetic $\left(\sim 3.0 \mathrm{~A} / \mathrm{m}\left(\kappa=8.0 \times 10^{-2} \mathrm{SI}\right)\right)($ Fig. $8(\mathrm{c}))$. The apparent magnetization intensity map implies that the felsic rocks in the eastern part are underlain by mafic rocks.

Although the general characteristics between the results of the apparent magnetization intensity mapping and rock magnetic measurements are well correlated, the actual rock magnetic properties tend to be higher than the apparent magnetization intensities, suggesting that the bottom depth of the pluton is shallower than the initial assumption $(16 \mathrm{~km}$ BSL) of the mapping. Thus, we tried to estimate the bottom depth of the pluton. We assumed an ensemble of vertical prisms with the horizontal boundaries deduced from a geologic map (Katada et al., 1991) for the North pluton (A and B) and an apparent magnetization intensity map (Fig. 8(c)) for the South pluton (C) as the magnetic structure, which is subject to the magnetic anomalies. We allowed variations of uniform bottom depths of vertical prisms for the North and South plutons individually, but fixed the tops to the terrain height. Synthetic magnetic anomalies (Fig. 8(d)), which best fit the observed residual anomalies (Fig. 8(b)), were calculated by trial and error, changing the bottom depths in terms of $100 \mathrm{~m}$ with rock magnetic data (Table 2).

We used the term of goodness-ratio $(r)$ (Vacquier and Uyeda, 1967) to judge how synthetic anomalies $(G)$ fit well to the observed anomalies $(F)$ : the larger the ratio, the better the fit.

Goodness-ratio $(r)$ can be written by

$$
r=\frac{\sum_{i=1}^{n}\left|F_{i}\right|}{\sum_{i=1}^{n}\left|F_{i}-G_{i}\right|}
$$




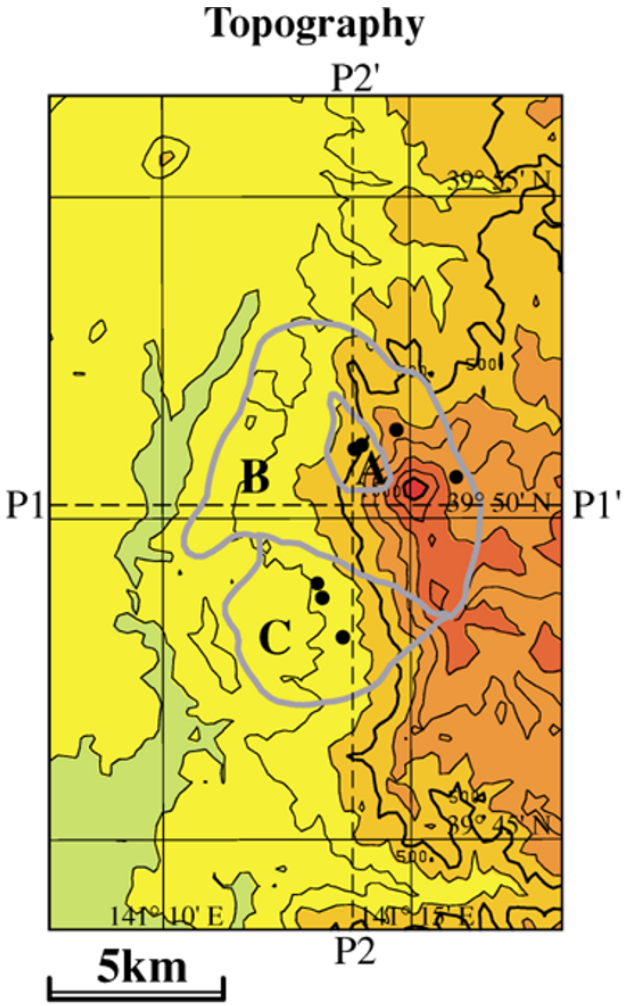

(a)

\section{Magnetization Intensity}

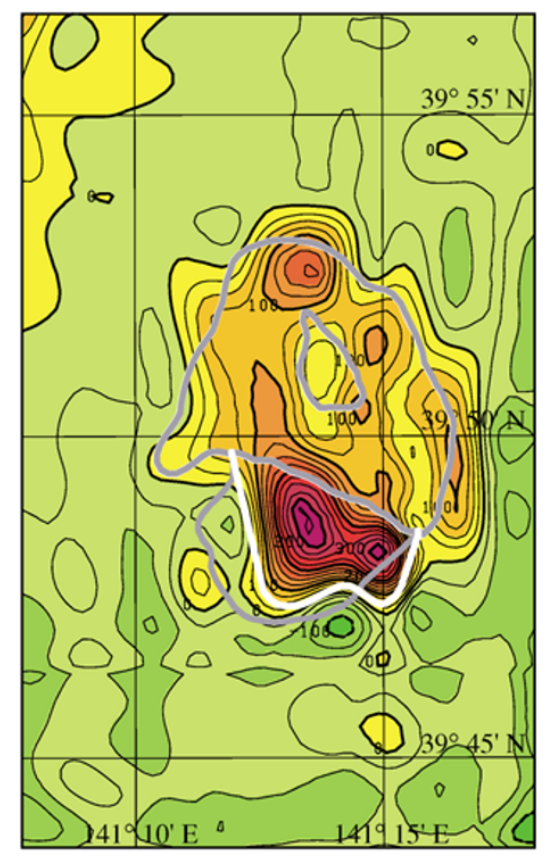

$5 \mathrm{~km}$
Total Magnetic Intensity
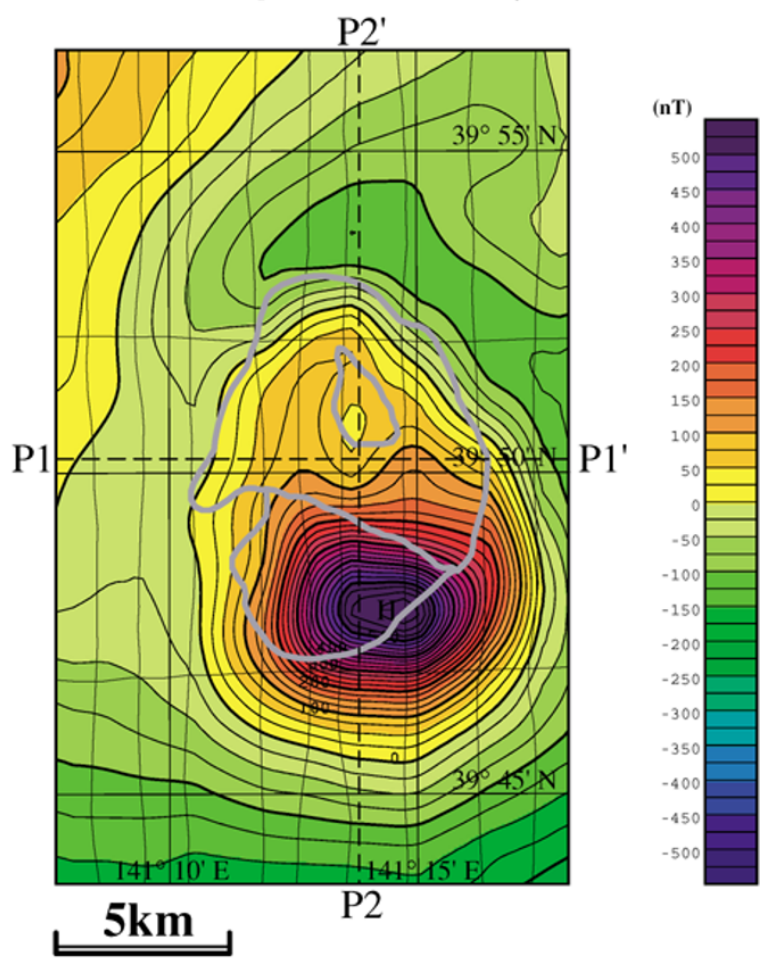

(b)
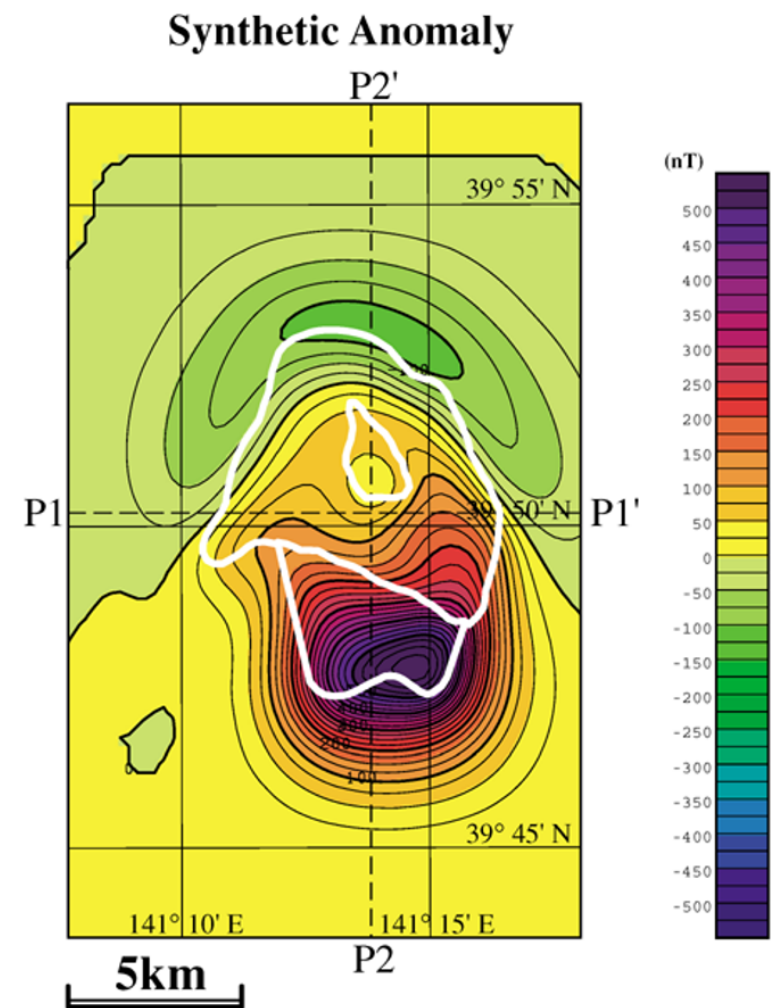

(c)

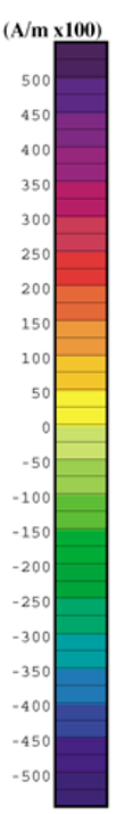

(d)

Fig. 8. Magnetic modeling of the Himekami pluton. (a) Topographic map of study area. Contour interval is $100 \mathrm{~m}$. Thick grey lines indicate geologic boundaries of the pluton (simplified from Katada et al., 1991). A and B denote less magnetic and magnetic parts of the North pluton, respectively. C is the South pluton. Black dots indicate rock sampling sites. (b) Total magnetic intensity anomaly map of study area (after Okuma and Suto, 1987). Contour interval is $25 \mathrm{nT}$. Specification of the original aeromagnetic survey by MITI is summarized in Table 1 . Thin black solid lines indicate flight lines, spaced 1-2 km apart. See also (a). (c) Apparent magnetization intensity map of study area. Contour interval is $25 \times 10^{-2} \mathrm{~A} / \mathrm{m}$. Thick white lines indicate geologic boundaries of the pluton estimated by the apparent magnetization mapping. See also (a). (d) Synthetic magnetic anomaly that best fits the observed one ((b)). Contour interval is $25 \mathrm{nT}$. See also (c). 


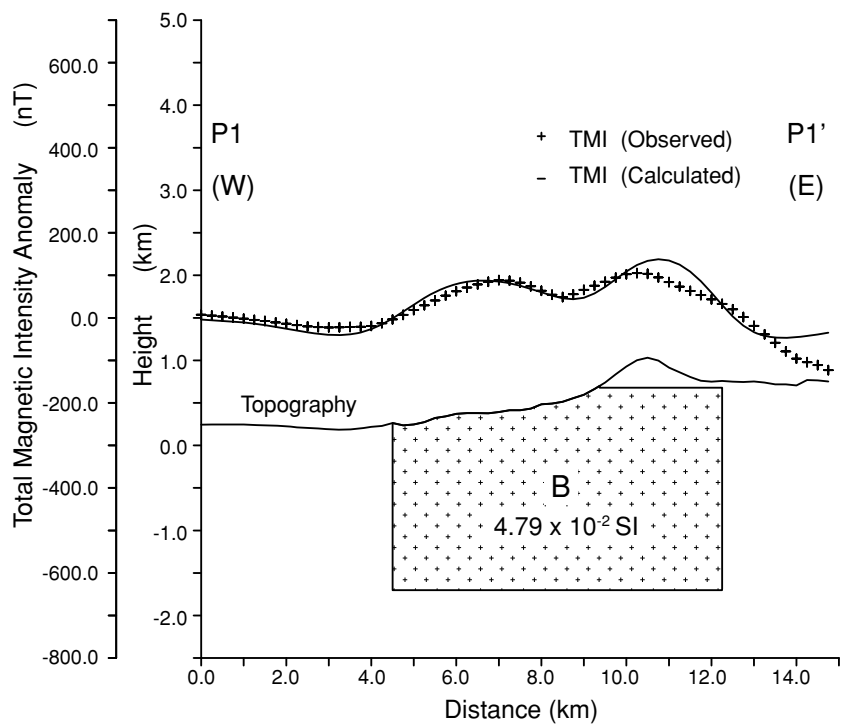

(a) E-W Profile

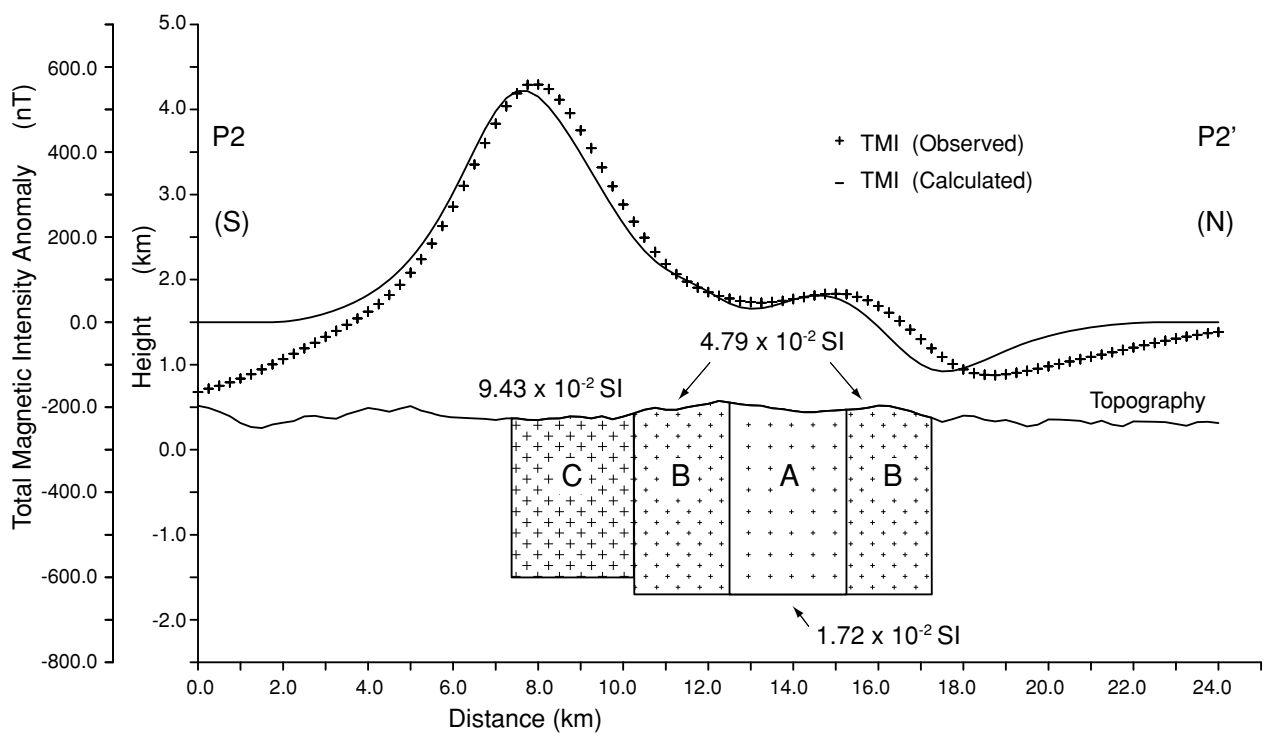

(b) N-S Profile

Fig. 9. Cross-sections of the magnetic model of the Himekami pluton. (a) E-W profile: East-West cross-section of an optimum magnetic model (Fig. 8(d)) which best fits the observed total magnetic intensity anomaly (Fig. 8(b)). Vertical exaggeration is 2.0. Numerals stand for magnetic susceptibilities employed for the magnetic modeling. See also Fig. 8(a). (b) N-S profile: North-South cross-section of an optimum magnetic model (Fig. 8(d)) which best fits the observed total magnetic intensity anomaly (Fig. 8(b)). See also Fig. 9(a).

Table 2. Rock magnetic properties of the Himekami pluton.

\begin{tabular}{cccccc}
\hline Body & $\begin{array}{c}\text { Magnetic Susceptibility } \\
\text { Average } \\
(\text { Standard Dev. }) \\
(\mathrm{SI})\end{array}$ & $\begin{array}{c}\text { NRM Intensity } \\
\text { Average } \\
(\text { Standard Dev. }) \\
(\mathrm{A} / \mathrm{m})\end{array}$ & $\begin{array}{c}\text { Qn* } \\
\text { ratio }\end{array}$ & $\begin{array}{c}\text { Number } \\
\text { of Sampling } \\
\text { Sites }\end{array}$ & $\begin{array}{c}\text { Number } \\
\text { of Rock } \\
\text { Specimens }\end{array}$ \\
\hline $\mathrm{A}$ & $\begin{array}{c}1.72 \times 10^{-2} \\
\left(4.09 \times 10^{-4}\right)\end{array}$ & $\begin{array}{c}2.09 \times 10^{-1} \\
\left(6.42 \times 10^{-2}\right)\end{array}$ & 0.32 & 2 & 6 \\
$\mathrm{~B}$ & $\begin{array}{c}4.79 \times 10^{-2} \\
\left(8.40 \times 10^{-3}\right)\end{array}$ & $\begin{array}{c}7.95 \times 10^{-1} \\
\left(2.51 \times 10^{-2}\right)\end{array}$ & 0.43 & 2 & 6 \\
$\mathrm{C}$ & $\begin{array}{c}1.93 \times 10^{0} \\
\left(4.43 \times 10^{-2}\right.\end{array}$ & 0.54 & 3 & 21 \\
\hline
\end{tabular}

*: The Earth's magnetic field of 47,500 nT was assigned for the calculation of Qn ratio. 


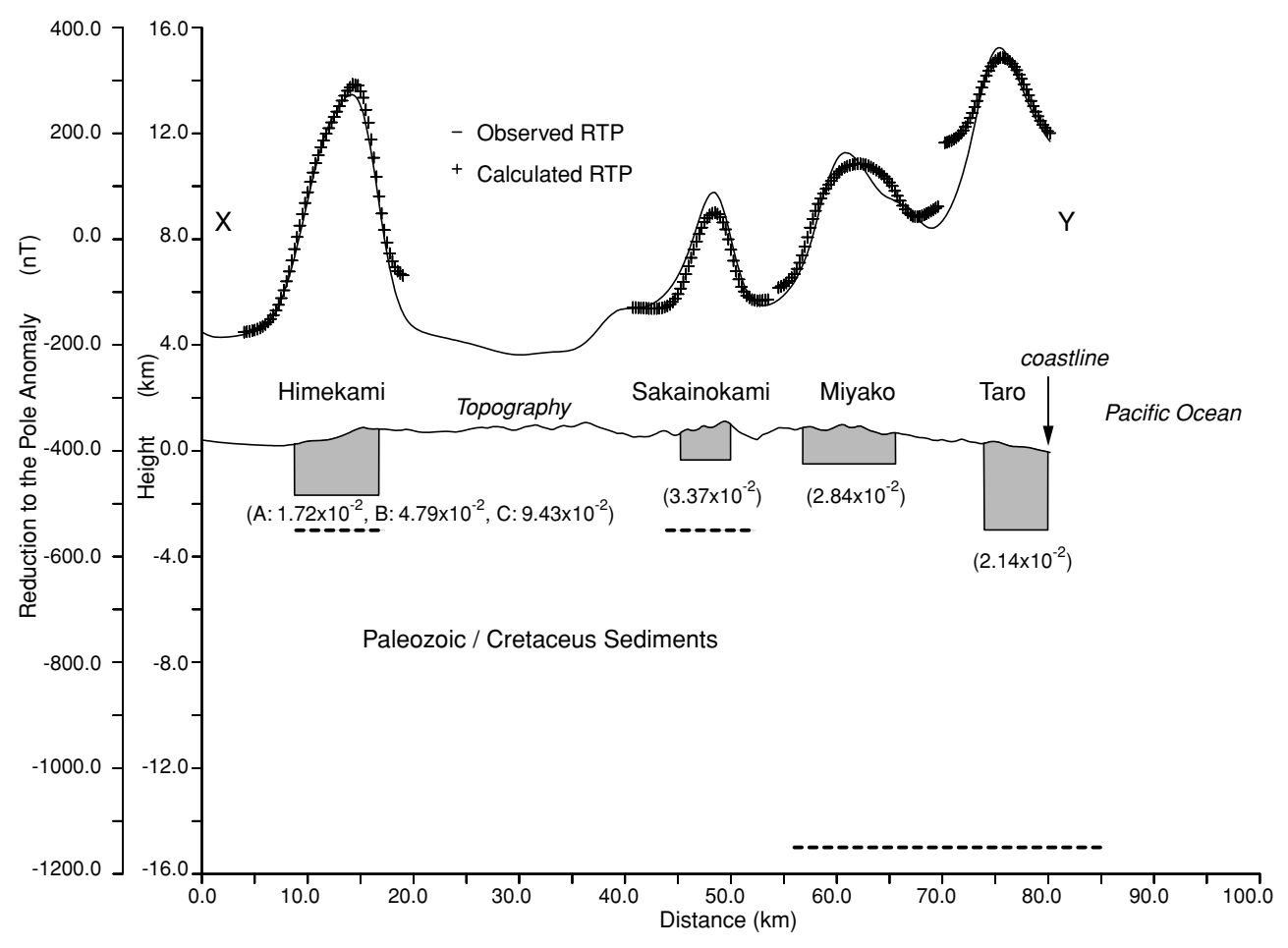

Fig. 10. Schematic cross-section of the magnetic structure along the profile X-Y. See the location of the profile in Fig. 1. A line and plus signs in the upper part of the figure indicate observed and calculated reduction to the pole anomalies (RTP), respectively. Vertical exaggeration is 2.5 for the structure. Grey areas denote cross-sections of the Kitakami plutons; Himekami, Sakainokami, Miyako and Taro from left to right, whose structures were estimated by individual magnetic modeling as isolated anomalies without regional trends. Numbers in parentheses denote averaged magnetic susceptibilities (SI) employed for magnetic modeling. Thick broken lines show the bottom depths of each pluton estimated by an MT modeling (Ogawa, 1992).

Assuming induced magnetization and the terrain higher than $750 \mathrm{~m}$ above sea level is not magnetized due to weathering and does not contribute to the magnetic anomalies, optimum bottom depths of the vertical prisms are $1.7 \mathrm{~km}$ and $1.5 \mathrm{~km}$ below sea level for the North and South plutons, respectively (Fig. 9). This corresponds to the largest goodness-ratio of 4.90. This result is a good example that implies bottom depths of satellite plutons of the Kitakami Granites are not always so thick (Fig. 10).

\subsection{Northern Miyagi Earthquake area}

The second example is a study over the 2003 Northern Miyagi Earthquake area (Fig. 11) where a series of strong earthquakes (JMA intensities $>5$ ) occurred during the period from July 26-28 in 2003. In this area, the Asahiyama Flexure has been known as an active fault (Research Group for Active Faults of Japan, 1991) but no surface faults caused by the recent earthquakes were observed. Seismic activity including fore- and aftershocks (most of them $<10$ $\mathrm{km}$ BSL) occurred in an inclined plane with a slope of about fifty degrees westward from the ground and the upward extension of the activity area reaches ground level $5 \mathrm{~km}$ east of the Asahiyama Flexure (Okada et al., 2003). In this area, the northwestern extension of the Ishinonmaki-wan Fault was thought to extend along the east flank of Sue Hill (Nakamura, 1990; Figs. 11, 12 and 13(a)) but has not been treated as a serious active fault that causes disastrous earthquakes.

A magnetic high occurs east of Sue Hill, north of Ishinomaki City (Fig. 13(c)), where small outcrops of one of the Kitakami plutons, called the Sobanokami pluton exists (Fig. 13(b)). This area corresponds to the southwestern edge of the Kitakami Mountains. The center of the area is covered by alluvium and is bounded by Miocene/Pliocene sedimentary rock to the west and by Triassic sedimentary rocks to the east.

Magnetic modeling was conducted by trial and error calculation along the WSW-ENE and NNW-SSE directions (Fig. 13(d)), assuming an ellipsoid as the magnetic source (Clark et al., 1986). When using an average magnetic susceptibility of the Sobanokami pluton from the petrophysical database, it is difficult to find a suitable solution for the analysis because of low magnetic susceptibility levels. The average magnetic susceptibility of the Sobanokami pluton $\left(3.00 \times 10^{-3} \mathrm{SI}\right)$ calculated from previous petrophysical measurements is conspicuously low compared to that of the Kitakami Granites $\left(2.69 \times 10^{-2} \mathrm{SI}\right)$. An additional sampling of the Sobanokami pluton has been conducted recently and implies that the previous petrophysical measurements were collected from outcrops close to contacts with sedimentary rocks. Magnetic susceptibility measurements of specimens from a newly-found outcrop of the pluton average $3.36 \times 10^{-2}$ SI (Table 3) and are almost equal to that of Zone VI $\left(3.31 \times 10^{-2} \mathrm{SI}\right)$. The average intensity of NRM and Qn ratio of the specimens from the outcrops are $2.25 \times 10^{-1}(\mathrm{~A} / \mathrm{m})$ and 0.18 , respectively. In this modeling, parameters of the optimum model are summarized in Table 4: the width (WSW-ENE), length (NNW-SSE) and height of the ellipsoid are $4000 \mathrm{~m}, 6000 \mathrm{~m}$ and $1650 \mathrm{~m}$, respec- 


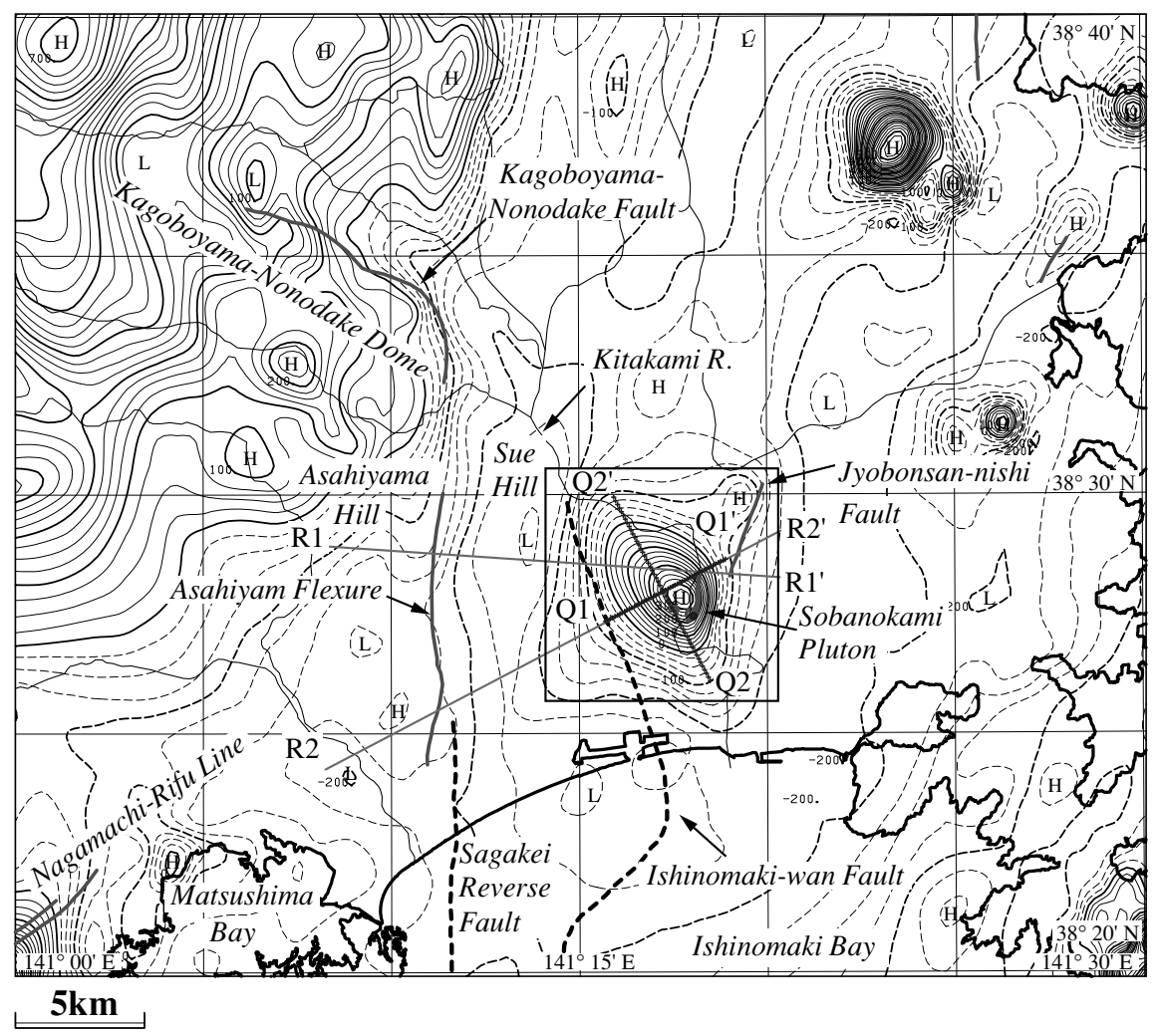

Fig. 11. Reduction to the pole anomaly map of the 2003 northern Miyagi earthquake area. Contour interval is 25 nT. This map was created from the total magnetic intensity anomaly map of the area (GSJ, 1974; Table 1). The rectangle bounded by solid line indicates the Sobanokami pluton area (Fig. 13). Line Q1-Q1' and Q2-Q2' show the locations of magnetic modeling profiles with an assumption of an ellipsoid model (Fig. 13). Line $\mathrm{R} 1-\mathrm{R} 1^{\prime}$ and R2-R2' show the locations of integrated gravity and magnetic 2-D modeling profiles (Fig. 15). See also Fig. 1.

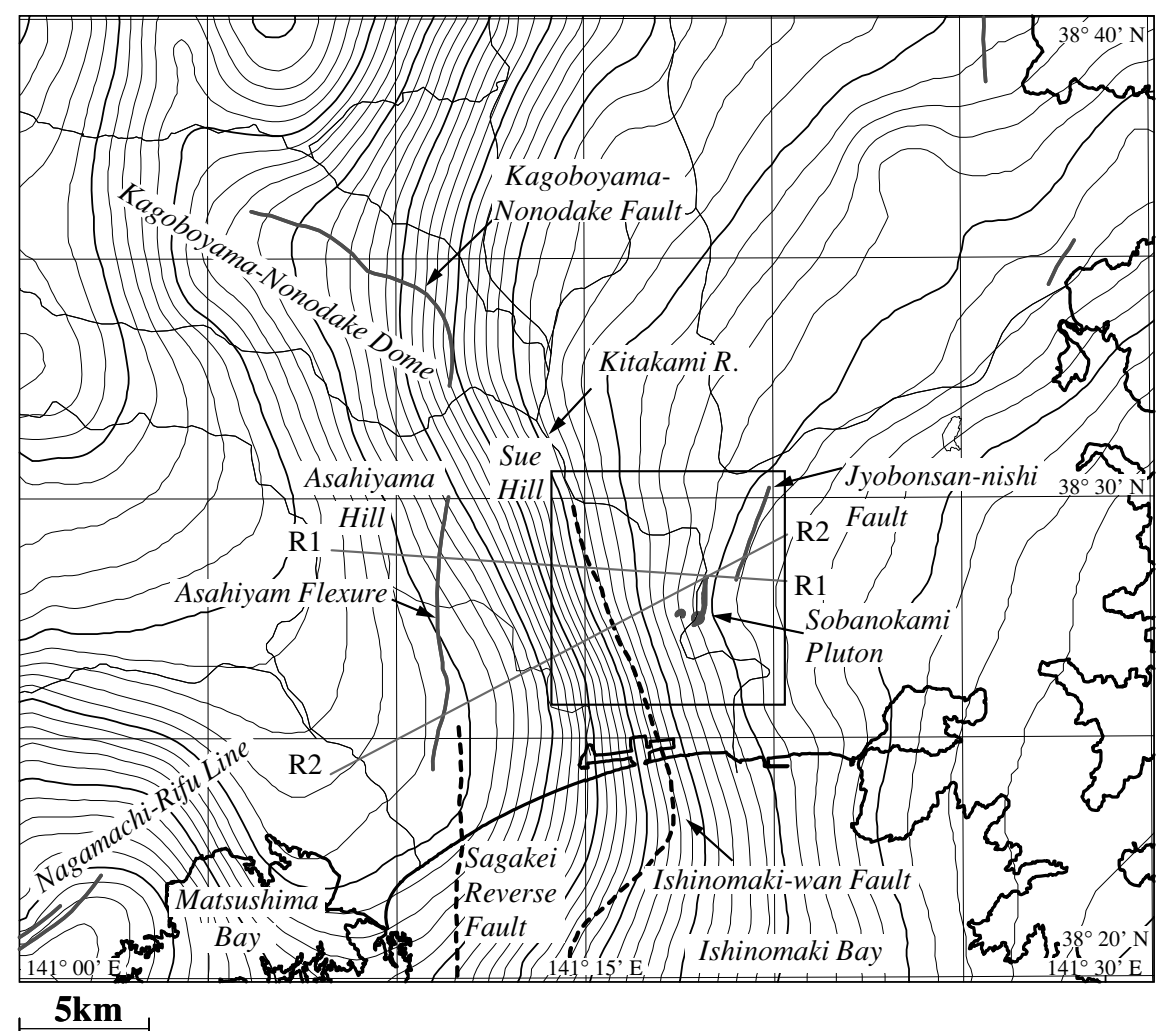

Fig. 12. Bouguer gravity map of the 2003 northern Miyagi earthquake area. Assumed Bouguer density: $2.67 \times 10^{3} \mathrm{~kg} / \mathrm{m}^{3}$. Contour interval is $2 \mathrm{mgal}$. This map was created from the gravity database by the GSJ (Komazawa, 2000). See also Fig. 11. 


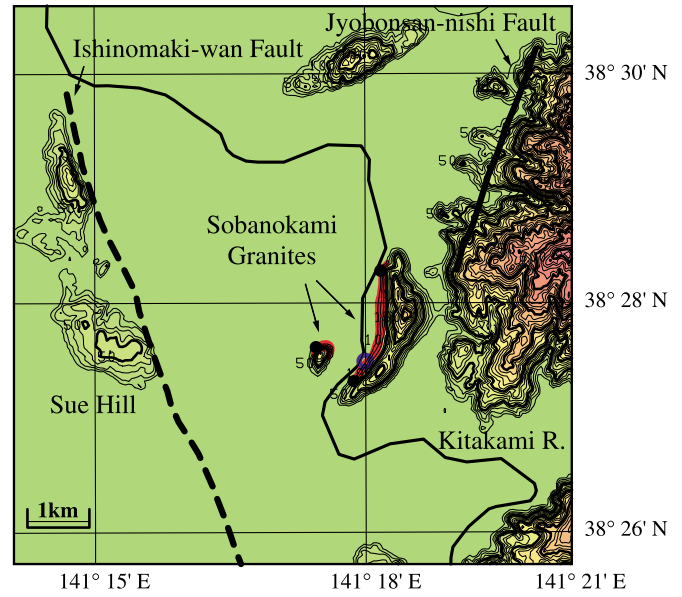

(a)

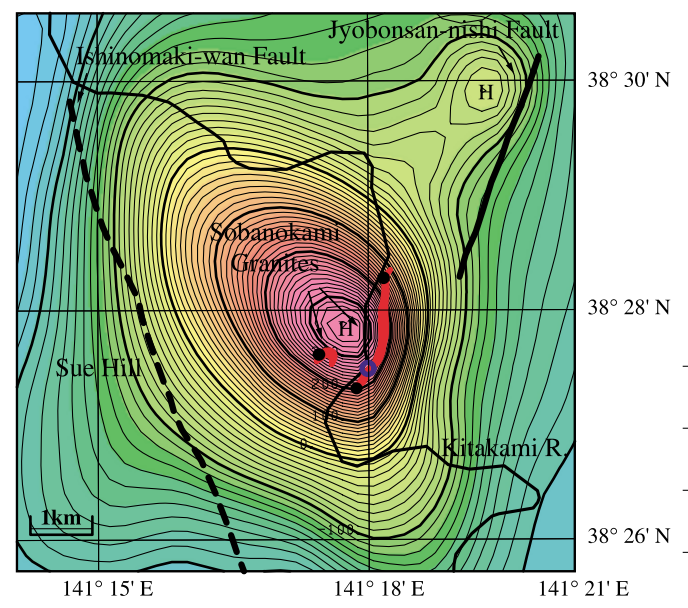

(c)
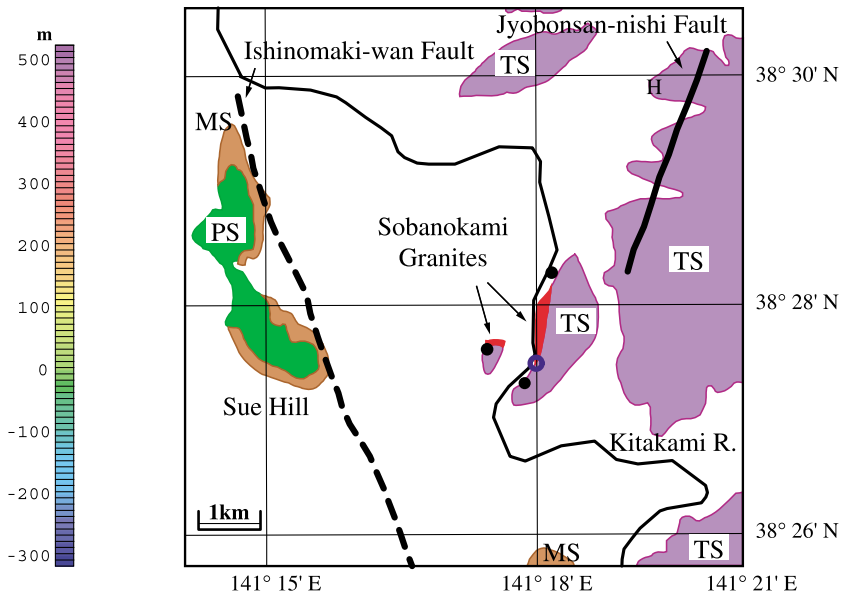

(b)

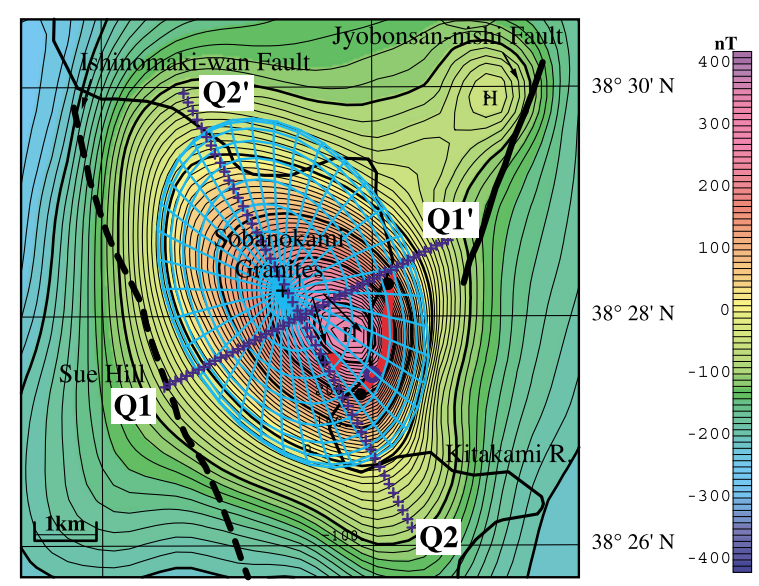

$141^{\circ} 15^{\prime} \mathrm{E}$

(d)

Fig. 13. Magnetic modeling of the Sobanokami pluton area. (a) Topographic map of study area. Contour interval is $10 \mathrm{~m}$. Thick black broken and solid lines indicate faults; Ishinomaki-wan fault (Nakamura, 1990) and Jyobonsan-nishi fault (Research Group for Active Faults of Japan, 1991) from west to east. Thick red solid lines show the outcrops of the Sobanokami pluton. Black dots and a blue open circle denote previous and new rock sampling sites, respectively. (b) Simplified geologic map of study area (modified from Takizawa et al., 1992). TS: Triassic sedimentary rocks, MS: Miocene sedimentary rocks, PS: Pliocene sedimentary rocks, no label: Alluvium. See also Fig. 13(a). (c) Reduction to the pole anomaly map of study area. Contour interval is $10 \mathrm{nT}$. See also Fig. 13(a). (d) Plan-view of a magnetic model. Crosses with Q1-Q1' and Q2-Q2' indicate the locations of the WSW-ENE and SSE-NNW modeling profiles in Fig. 14, respectively. Light blue lines denote the wire frame of a magnetic ellipsoid. See also Fig. 13(c).

Table 3. Rock properties of the Sobanokami pluton.

\begin{tabular}{|c|c|c|c|c|c|c|c|}
\hline \multirow{2}{*}{$\begin{array}{c}\text { Magnetic } \\
\text { Susceptibility } \\
\text { Average } \\
\text { (Standard Dev.) } \\
\text { (SI) }\end{array}$} & \multicolumn{3}{|c|}{ NRM } & \multirow{2}{*}{$\begin{array}{l}\text { Qn* } \\
\text { ratio }\end{array}$} & \multirow[b]{2}{*}{$\begin{array}{c}\text { Density } \\
\text { Dry } \\
(\text { Wet }) \\
\left(x 10^{3} \mathrm{~kg} / \mathrm{m}^{3}\right)\end{array}$} & \multirow{2}{*}{$\begin{array}{c}\text { Number } \\
\text { of Sampling } \\
\text { Sites }\end{array}$} & \multirow{2}{*}{$\begin{array}{c}\text { Number } \\
\text { of Rock } \\
\text { Specimens }\end{array}$} \\
\hline & $\begin{array}{c}\text { Intensity } \\
\text { Average } \\
\text { (Standard Dev.) } \\
(\mathrm{A} / \mathrm{m})\end{array}$ & $\begin{array}{l}\text { Inc. } \\
\text { (deg.) }\end{array}$ & $\begin{array}{l}\text { Dec. } \\
\text { (deg.) }\end{array}$ & & & & \\
\hline $\begin{array}{c}3.36 \times 10^{-2} \\
\left(3.84 \times 10^{-3}\right)\end{array}$ & $\begin{array}{c}2.25 \times 10^{-1} \\
\left(1.05 \times 10^{-1}\right)\end{array}$ & 62.6 & -30.1 & 0.18 & $\begin{array}{l}2.76 \\
(2.77) \\
\end{array}$ & 2 & 24 \\
\hline
\end{tabular}

*: The Earth's magnetic field of 47,500 nT was assigned for the calculation of Qn ratio.

tively, and the top depth of the ellipsoid is just beneath the ground and bottom depth ranges from 800 to $2000 \mathrm{~m}$ with a thickness of $1650 \mathrm{~m}$ (Fig. 14). NRM was ignored in this modeling. As the NRM direction of the Sobanokami pluton is close to that of the present Earth's magnetic field (Table 3), composite magnetic susceptibility can be calculated to be about $4 \times 10^{-2}$ SI by summation. Thus, if we take into count NRM of the pluton, the thickness of the ellipsoid is estimated to be $1200 \mathrm{~m}$.

\section{Discussions \\ 6.1 Himekami pluton}

Three-dimensional magnetic modeling of the Himekami pluton (this study) and similar modeling of Sakainokami, 


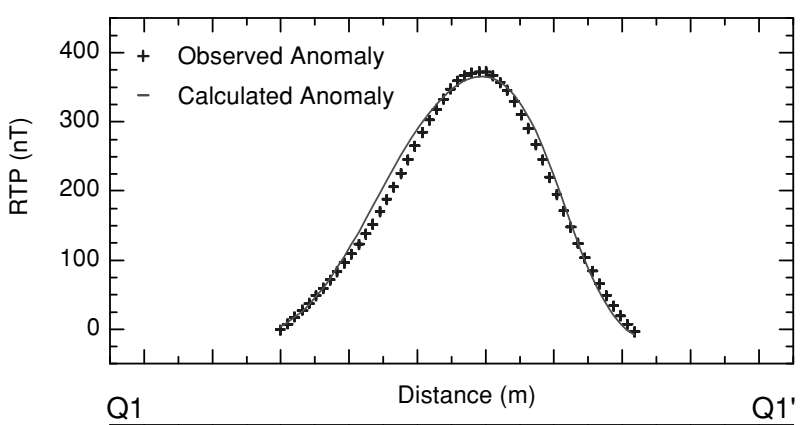

$-2000-1000 \quad 0 \quad 1000200030004000500060007000$

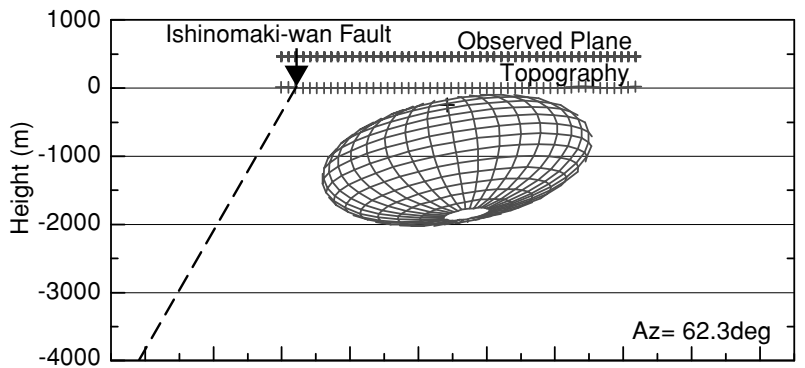

(a)
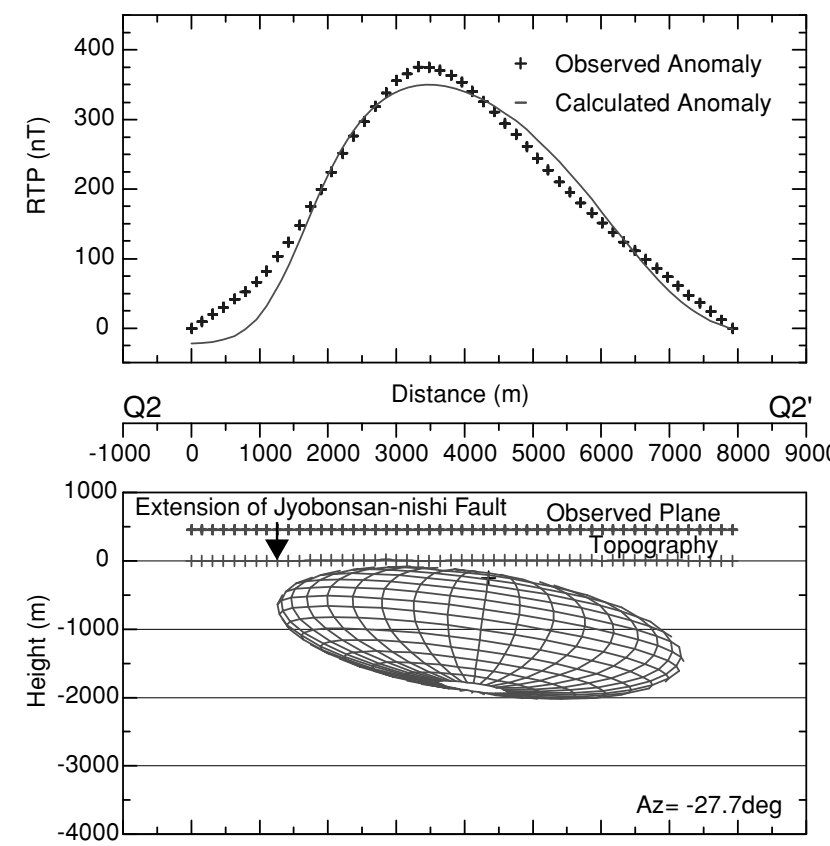

(b)

Fig. 14. Cross-sections of the magnetic model for the Sobanokami pluton area. (a) WSW-ENE cross-section (Q1-Q1'). See the location of the profile in Fig. 13(d). Crosses and a line in the upper part of the figure denote observed and synthetic reduction to the pole anomalies, respectively. A wire frame structure shows a magnetic ellipsoid. The location of the Ishinomaki-wan fault was indicated with a solid arrow and broken line. (b) SSE-NNW cross-section $\left(\mathrm{Q} 2-\mathrm{Q}^{\prime}\right)$. The estimated extension of the Jyobonsan fault was indicated with a solid arrow. See also Fig. 14(a).

Table 4. Model parameters of the Sobanokami pluton.

\begin{tabular}{cccccccc}
\hline Profile & $\begin{array}{l}\mathrm{A}^{*} \\
(\mathrm{~m})\end{array}$ & $\begin{array}{c}\mathrm{B}^{*} \\
(\mathrm{~m})\end{array}$ & $\begin{array}{c}\mathrm{C}^{*} \\
(\mathrm{~m})\end{array}$ & $\begin{array}{c}\text { Strike } \\
(\text { deg.) }\end{array}$ & $\begin{array}{c}\text { Dip* } \\
(\mathrm{deg} .)\end{array}$ & $\begin{array}{c}\text { Plunge* } \\
(\text { deg. })\end{array}$ & $\begin{array}{c}\text { Magnetic Susceptibility } \\
(\mathrm{SI})\end{array}$ \\
\hline $\mathrm{A}^{\prime} \mathrm{A}^{\prime}$ & 4000 & 6000 & 1650 & -27.7 & -10.0 & 8.0 & $3.36 \times 10^{-2}$ \\
\hline
\end{tabular}

A, B, C: Width, length and height of an ellipsoid along three semi-axes.

Strike: Azimuth of plunge of the axis along the width from the east, Dip: Plunge of the axis (positive direction) along the width from the horizontal plane, Plunge: Plunge of the axis along the length from the plane containing axes along the width and length.

Miyako and Taro plutons (in preparation) in the north Kitakami Mountains constrained with magnetic susceptibilities averaged from rock magnetic data reveal the subsurface structure of the plutons. The results show that the bottom depths of these plutons are $1.5 \sim 1.7 \mathrm{~km}, 0.35 \mathrm{~km}, 0.5 \mathrm{~km}$ and $3.0 \mathrm{~km}$ below sea level, respectively (Fig. 10).

In this area, a magnetotelluric (MT) survey was conducted along a E-W profile and the result of a 2-D inversion suggested the bottom depths of the resistive Himekami pluton (100-1000 $\Omega \cdot \mathrm{m})$, Sakainokami and Miyako plutons (both $>1000 \Omega \cdot \mathrm{m}$ ) are $3 \mathrm{~km}, 3 \mathrm{~km}$ and $15 \mathrm{~km}$ below sea level, respectively (Ogawa, 1992; Fig. 10). The relative depth variations in both magnetic and resistivity models are similar, although there is a discrepancy in the bottom depth of the plutons between the magnetic and MT results. This discrepancy might be caused partly by the less accurate assumption of magnetic susceptibility for magnetic modeling. The reliability of depth estimation by magnetic modeling depends chiefly on determination of proper rock magnetic properties. As for the Himekami pluton, the standard deviation of magnetic susceptibility of rock samples from the
South pluton $(\mathrm{C})$ is relatively large while those from the North pluton are small (Table 2). This is because C comprises felsic and mafic parts (Katada et al., 1991). The averaged magnetic susceptibilities of felsic and mafic parts are about $6.34 \times 10^{-2}(\mathrm{SI})$ and $1.56 \times 10^{-1}(\mathrm{SI})$, respectively. If we adopt the MT result and assume the bottom depth of $\mathrm{C}$ is $3 \mathrm{~km}$ below sea level, an optimal magnetic susceptibility of $\mathrm{C}$ is $7.80 \times 10^{-2}(\mathrm{SI})$. In this case, the ratio of felsic to mafic parts can be estimated to be approximately $5: 1$, whereas the proportion of mafic parts is estimated to be less than 5 percent according to the geologic map (Katada et al., 1991). This implies the felsic parts of $\mathrm{C}$ are underlain by more mafic parts than observed at the surface.

The accuracy of MT modeling is another cause for the discrepancy. Three-dimensional structures of the plutons should also be taken into account for MT modeling, because dimensions of the satellite plutons are not big enough to assume a 2-D model in some cases (e.g. Sakainokami pluton: $3 \times 5 \mathrm{~km})$.

Furthermore, uncertainty remains in the analyses of magnetic anomalies on the coast of the Kitakami Mountains. As 
shown in a magnetic profile (Fig. 10), a regional magnetic high is superimposed on local magnetic highs close to the coast. Before the magnetic modeling of satellite plutons, these regional trends had been removed, and their effect is not included in the result of the modeling at this stage. In these areas, composite magnetic modeling considering 2-D and 3-D structures is necessary.

On the Pacific coast of the Kitakami massif, distinctive linear N-S positive magnetic anomalies had been observed from the western part of Hokkaido and named KitakamiIshikari Magnetic Belt (Ogawa and Suyama, 1976; Oshima et al., 1975; Fig. 1). Segawa and Furuta (1978) conducted an analysis of these positive magnetic anomalies along the latitude of 41 degrees $\mathrm{N}$ and estimated a volcanic structure at a depth of $5 \mathrm{~km}$ below sea level with a thickness of 10 $\mathrm{km}$, assuming a northwestward declination of magnetization although a low Qn ratio less than 0.5 of volcanic core samples from the bottom of two drill holes in the anomaly area in Hokkaido was observed.

Finn (1994) attributed the linear positive anomalies to the Kitakami Granites on the basis of the existence of the Kitakami Granite at the bottom of a drill hole, off-Kesennuma (\#3 in Fig. 1; Japan Natural Gas Association and Japan Offshore Petroleum Development Association, 1986), with KAr ages of $121 \pm 4$ and $111 \pm 4$ for biotite and K-feldspar, respectively (Shibata, 1986). She also set the bottom depth of the batholiths around $16 \mathrm{~km}$ below sea level, referring to a resistivity cross-section by an MT survey (Ogawa, 1992) and a refraction seismic survey (Iwasaki et al., 1994).

Although the positive linear magnetic anomalies on the Pacific coast of the northern Kitakami Mountains seem to have a close relationship with the distribution of the $\mathrm{Ki}$ takami Granites, we should be careful in examining the origin of magnetic anomalies in the area. Actually, the Harachiyama Formation composed of felsic, intermediate and mafic volcanic rocks, outcrops along the Pacific coast of the northern Kitakami Mountains close to the Kitakami plutons such as in Zone I and II (Figs. 3 and 7). The Harachiyama Formation was formed in the Early Cretaceous just before the intrusion of the Kitakami Granites and is believed to form a Cretaceous volcano-plutonic complex with the Kitakami plutons (Kanisawa, 1974). Felsic parts of the Harachiyama Formation do not show strong magnetic properties (Otofuji et al., 1997) but mafic-intermediate parts of the formation might cause magnetic anomalies because of magnetic susceptibilities as high as the Kitakami Granites (in preparation). Cretaceous mafic volcanic rocks were retrieved as cuttings from the bottom of the drill hole Off-Hachinohe (\#1 in Fig. 1; Japan Natural Gas Association and Japan Offshore Petroleum Development Association, 1992) just below the eastern magnetic high of the KitakamiIshikari Magnetic Belt and might correspond to a northern extension of the Harachiyama Formation.

Furthermore, many granitic rocks of the Kitakami plutons are closely associated with gabbroic rocks (Kanisawa and Katada, 1988). Although gabbroic rocks of Zone I, II and V occupy smaller volumes than the rocks of Zone III, IV and VIb, the large amplitude of magnetic anomalies (Figs. 1 and 7) suggests the granitic rocks are underlain by more gabbroic rocks than observed on the surface. Further rock magnetic measurements are necessary to clarify this problem.

\subsection{Northern Miyagi Earthquake area}

In the 2003 northern Miyagi earthquake area, steep gravity gradients (Fig. 12) indicate a major boundary between the Kitakami massif and Tertiary-Quaternary sedimentary rocks (Komazawa et al., 1996). However, it has not been thought to be associated with active faults which might cause severe earthquakes due to the cover of Quaternary sediments.

Umino et al. (2003) conducted a temporal seismic observation right after the 2003 northern Miyagi earthquake (M6.4) and showed that the fault plane is a curved surface: the northern part of the plane dips to the west at an angle of $\sim 50$ degrees and the southern part to the northwest at $\sim 40$ degrees. As the upward extension of the depth distribution of aftershocks coincides with surface trace of the Ishinomaki-wan fault, they thought the rupture of the M6.4 earthquake took place along the fault at a depth of 3-12 km.

On the other hand, reflection seismic surveys were conducted after the earthquake to reveal the subsurface structure of the area and the extension of a buried fault associated with the recent earthquakes is assumed to exist along the east flank of Sue Hill (e.g. Sato et al., 2004; Yokokura et al., 2004). Sato et al. (2004) showed that Miocene sediments of the rift and post-rift stages such as the Kakeyama Formation and Pliocene sediments are underlain by Pre-Tertiary basement to the west of the Ishinomaki-wan fault.

The Kakeyama Formation is a basal conglomerate composed of cobbles and boulders which were supplied from pre-Tertiary rocks such as shale, sandstone, granitic rocks and chert (Takizawa et al., 1992). It is assumed that the formation was deposited in a half-graben bounded by the Ishinomaki-wan fault to the east during early Miocene age (Sato et al., 2004). The formation was uplifted by reverse faulting of the Ishinomaki-wan fault in late Pliocene and the eastern edge of the formation crops out west of the fault (Nakamura, 1992). Reflection seismic surveys (Sato et al., 2004; Yokokura et al., 2004) revealed that the main part of the formation is overlain by Pliocene and Pleistocene sediments and some dips to the west are about 30 degrees. A portion of the magnetic high which corresponds to the Sobanokami pluton extends further to the southeast (Fig. 11). It might support the idea of the subsurface existence of conglomerates which include granitic rocks. However, the gradient of the Bouguer gravity (Fig. 12) is the steepest west of the fault not right on the fault contact, implying the density of the Kakeyama Formation which abuts on the fault contact is comparable with that of Paleozoic and Cretaceous sedimentary rocks.

Integrated 2-D modeling of magnetic and gravity anomalies (e.g. Talwani, 1965) was additionally conducted to address the problems raised above. The Sobanokami pluton was not imaged on reflection seismic and gravity crosssections (Sato et al., 2004), because there is no density contrast between the pluton and its surrounding Paleozoic/Mesozoic sedimentary rocks. In contrast, the pluton was imaged successfully by magnetic modeling in the previous chapter. Thus, the magnetic structure modeled for the Sobanokami pluton was incorporated into the seismic 

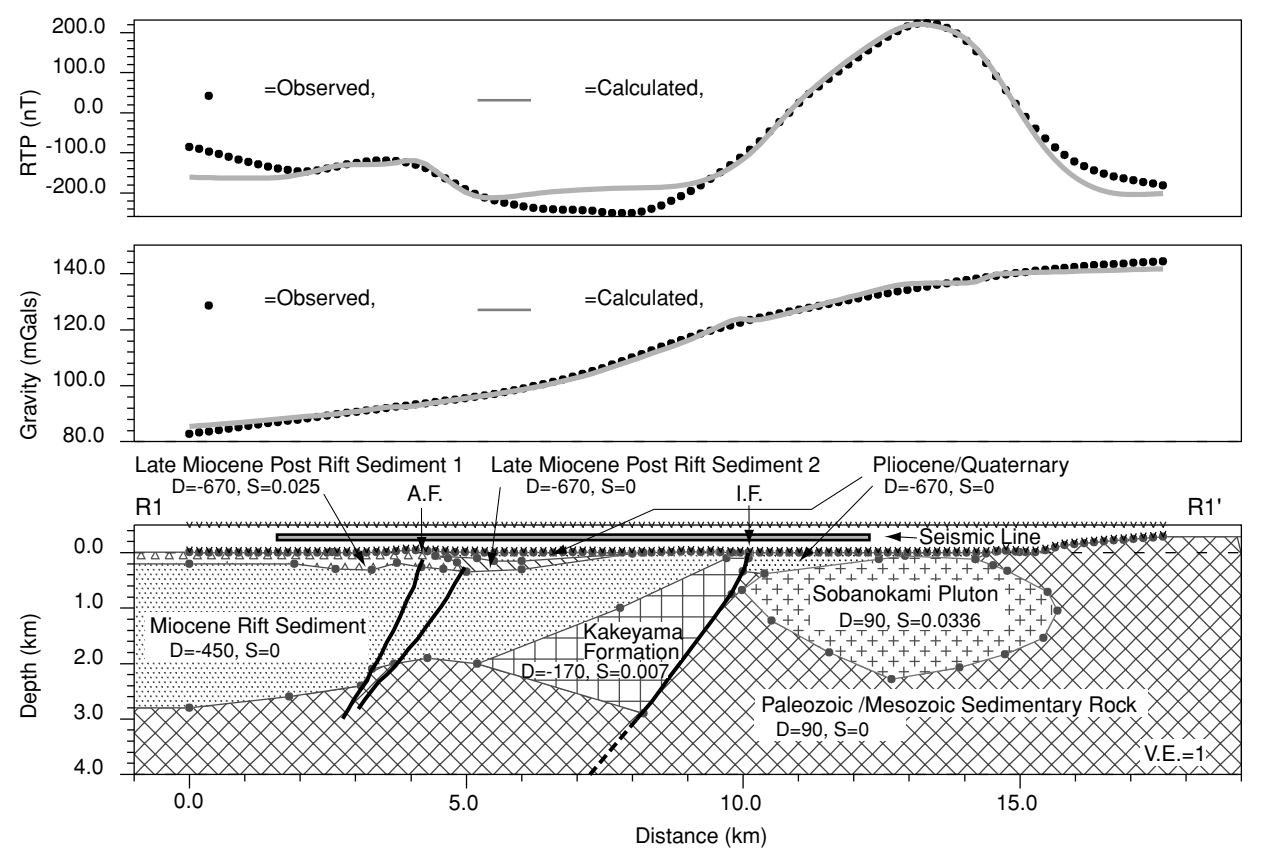

Fig. 15. Cross-section of the subsurface structure of the 2003 northern Miyagi earthquake area estimated by integrated gravity and magnetic modeling. See the location of the profile R1-R1' in Figs. 11 and 12. The profile was set along the seismic reflection study (Sato et al., 2004). D: Relative density to the assumed density for Bouguer correction of $2.67 \times 10^{3} \mathrm{~kg} / \mathrm{cm}^{3}$. S: Magnetic susceptibility (SI). The block of the Sobanokami pluton has finite lengths of 3 and $5 \mathrm{~km}$ in the plus and minus strike directions, respectively while other blocks have infinite lengths. I.F. and A.F. indicate the Ishinomaki-wan Fault and Asahiyama Flexure, respectively. A horizontal bar shows the location of a reflection seismic survey line (Sato et al., 2004).

cross-section (Fig. 15). Another magnetic structure was modeled on and around the Asahiyama Flexure, representing Miocene volcanic rocks. The density of the Sobanokami pluton and Paleozoic/Mesozoic sedimentary rocks was assumed to be $2.76 \times 10^{3} \mathrm{~kg} / \mathrm{m}^{3}$ after the rock property measurements (Table 3) and is almost equal to the averaged value of the Kitakami Granites $\left(2.77 \times 10^{3} \mathrm{~kg} / \mathrm{m}^{3}\right)$ (Fig. 5). The cross-section of the profile R1-R1' (Fig. 15(a)) along the reflection survey line indicates the Kakeyama Formation is relatively dense $\left(2.50 \times 10^{3} \mathrm{~kg} / \mathrm{m}^{3}\right)$ and slightly magnetic (magnetic susceptibility: $7.0 \times 10^{-3} \mathrm{SI}$ ). Furthermore, if we take a cross-section of the profile R2-R2' along the southwestern extension of a magnetic high (Fig. 11), this portion of the formation is analyzed to be more magnetic (magnetic susceptibility: $1.0 \times 10^{-2} \mathrm{SI}$ ) than the model of Fig. 15 . This suggests the southern part of the Kakeyama Formation contains more granitic fragments as conglomerate than the northern part, probably because of its closeness to the pluton's exposure.

\section{Conclusions}

We have described the utility of petrophysical and geophysical data to better understand the subsurface structure of the Kitakami plutons, northeast Japan. The petrophysical database, PB-Rock 21 indicates the Kitakami Granites are the most magnetic among Cretaceous to Paleogene granitic rocks in northeast Japan. Apparent magnetization mapping has been confirmed to be useful in constraining the magnetic properties of the Kitakami Granites by comparing rock magnetic data with the resultant magnetization map. Three-dimensional magnetic modeling using rock magnetic data revealed that the bottom depths of the Himekami plu- ton and other satellite plutons are apparently shallower than those estimates from 2-D MT modeling. Magnetic modeling in the 2003 northern Miyagi earthquake area determines the subsurface extension of the Sobanokami pluton which crops out partly at the southwestern edge of the Kitakami massif and is bounded by the Ishinomaki-wan fault to the west. Integrated magnetic and gravity modeling suggested granitic fragments from the Sobanokami pluton included in the Kakeyama Formation increase toward the south.

Acknowledgments. We are indebted to Tadashi Nakatsuka for the geophysical processing and mapping programs (Nakatsuka, 2003) to plot almost all the maps in this paper. We are grateful to Yasuaki Murata for providing a program, JKGLIB ver. 1 to plot geologic maps of northern Tohoku. We would like to thank two referees, Carol Finn (US Geological Survey) and Mark Pilkington (Geological Survey of Canada) for their helpful comments to improve the manuscript.

\section{References}

Clark, D. A., S. J. Saul, and D. W. Emerson, Magnetic and gravity anomalies of a triaxial ellipsoid, Exploration Geophysics, 17, 189-200, 1986.

Finn, C., Aeromagnetic evidence for a buried Early Cretaceous magmatic arc, northeast Japan, J. Geophys. Res., 99, 22165-22185, 1994.

Geological Survey of Japan, Total intensity aeromagnetic map of the coast of Kesennuma-Iwanuma area (1:200,000), VI-1, Total Intensity Aeromagnetic Map Series, 1974.

Geological Survey of Japan, Geologic Map of Japan, 1:1,000,000 (3rd Ed.), CD-ROM Version, Digital Geoscience Map, G1, 1995.

Iwasaki, T., T. Yoshii, T. Moriya, A. Kobayashi, M. Nishiwaki, T. Tsutsui, T. Iidaka, A. Ikami, and T. Masuda, Precise P and S wave velocity structures in the Kitakami massif, Northern Honshu, Japan, from a seismic refraction experiment, J. Geophys. Res., 99, 22187-22204, 1994.

Japan Natural Gas Association and Japan Offshore Petroleum Development Association, Recent oil exploration in Japan, 281 pp., Tokyo, Japan, 1986 (in Japanese). 
Japan Natural Gas Association and Japan Offshore Petroleum Development Association, Recent oil exploration in Japan (revised edition), 520 pp., Tokyo, Japan, 1992 (in Japanese).

Jolivet, L., K. Tamaki, and M. Fournier, Japan Sea, Opening history and mechanism: A synthesis, J. Geophys. Res., 99, 22237-22259, 1994.

Kanaya, H., V. Potassium, thorium, uranium and magnetic susceptibility, Cretaceous Granitic Rocks in the Kitakami Mountains-Petrography and Zonal Arrangement, Geol. Surv. Japan Report, 251, 91-103, 1974 (in Japanese with English abstract).

Kanaya, H. and M. Katada, Contents of thorium, uranium and potassium, and magnetic susceptibility of the permian Toyama and usugine facies in the Southern Kitakami mountains, Bull. Geol. Surv. Japan, 26, 13-27, 1975 (in Japanese with English abstract).

Kanaya, H. and S. Okuma, Petrophysical properties of Cretaceous to Paleogene granitic rocks in Japan: Part 1. A case of the northern Tohoku region, Bull. Geol. Surv. Japan, 54, 221-233, 2003.

Kanaya, H., M. Katada, and M. Nagahara, Physical properties of the Miyamori ultramafic complex in the Kitakami Mountains, northeast Japan, J. Japan Mineral. Petrol. Econ. Geol., 93, 71-82, 1998 (in Japanese with English abstract).

Kanisawa, S., Granitic rocks closely associated with the lower Cretaceous volcanic rocks in the Kitakami Mountains, northeast Japan, J. Geol. Soc. Japan, 80, 355-367, 1974.

Kanisawa, S. and M. Katada, Characteristics of Early Cretaceous igneous activity, Kitakami Mountains, Northeast Japan, Earth Science, 42, 220236, 1988 (in Japanese with English abstract).

Kano, H. and Research group of Granite plutons, Akita Univ., Structural Petrology of Granite plutons in the Kitakami Mountainlands, Japan, J. Japan Mineral. Petrol. Econ. Geol., 73, 97-120, 1978.

Katada, M., I. Introductory remarks, Cretaceous Granitic Rocks in the Kitakami Mountains-Petrography and Zonal Arrangement, Report of Geol. Surv. Japan, 251, 1-7, 1974 (in Japanese with English abstract).

Katada, M., K. Takahashi, and I. Fujiwara, Petrography of the Himekami pluton in the northwest Kitakami Mountains, J. Japan Mineral. Petrol. Econ. Geol., 86, 91-99, 1991 (in Japanese with English abstract).

Komazawa, M., Gravity Grid Database of Japan, Gravity CD-ROM of Japan, Digital Geoscience Map, P-2, Geol. Surv. Japan, 2000.

Komazawa, M., R. Morijiri, T. Hiroshima, M. Makino, Y. Murata, T. Ishihara, K. Nishimura, T. Nakatsuka, A. Nabetani, K. Noritomi, and M. Mishina, Gravity map of the Kitakami district (Bouguer Anomalies), Gravity Map Series, 7, Geol. Surv. Japan, 1996.

Maruyama, S. and T. Seno, Orogeny and relative plate motions: Example of the Japanese Islands, Tectonophysics, 127, 305-329, 1986.

Nabetani, S., H. Kano, K. Noritomi, K. Takagi, M. Suzuki, and Y. Fujimoto, Gravimetric Investigation on Granite plutons in the Kitakami Mountainlands, Northeast Japan; No. 1: Tono District, Butsuri-Tansa (Geophys. Explor.), 25, 153-167, 1972 (in Japanese with English abstract).

Nakamura, K., Geological Map off Kinkasan, 1:200,000, Marine Geology Map Series, 33, Geol. Surv. Japan, 1990.

Nakamura, K., Inversion tectonics and its structural expression, J. Tectonic Res. Group Japan, 38, 3-45, 1992 (in Japanese with English abstract).

Nakatsuka, T., Minimum norm inversion of magnetic anomalies with application to aeromagnetic data in the Tanna area, central Japan, J. Geomag. Geoelectr., 47, 295-311, 1995.

Nakatsuka, T., Library software for geophysical data processing and representation. GSJ Openfile Report, no. 400, 86 pp. + 1 CD-ROM, Geol. Surv. Japan, AIST, 2003.

Ogawa, K. and J. Suyama, Distribution of aeromagnetic anomalies, Hokkaido, Japan and its geologic interpretation, in Volcanoes and Tectonosphere: Tokai, Japan, edited by H. Aoki, and S. Iizuka, pp. 207215, Tokai Univ. Press, 1976.

Ogawa, Y., Deep crustal resistivity structure revealed by wideband magnetotellurics-Tohoku and Hokkaido region, Ph.D. Thesis, Univ. of Tokyo, 1992.

Oide, K., H. Nakagawa, and S. Kanisawa, Regional Geology of Japan, Part 2 Tohoku, Kyoritsu Shuppan, 338 pp., 1989 (in Japanese).

Okada, T., N. Umino, and A. Hasegawa, Rupture process of the July 2003 northern Miyagi earthquake sequence, NE Japan, estimated from double-difference hypocenter locations, Earth Planets Space, 55, 741-
$750,2003$.

Okuma, S., An interpretation of magnetic anomalies in the Northern Tohoku district, Japan: The result of an application of a two-layer model inversion to magnetic anomalies in the Hokuroku district and its relation to the distribution of metallic ore deposits, Bull. Geol. Surv. Japan, 44 193-217, 1993 (in Japanese with English abstract).

Okuma, S. and H. Kanaya, Rock Magnetism and Magnetic Survey, Chishitsu News, 428, 20-26, 1990 (in Japanese).

Okuma, S. and S. Suto, Magnetic structure of the Sengan geothermal area, Rept. Geol. Surv. Japan, 266, 425-447, 1987 (in Japanese with English abstract).

Okuma, S., T. Tosha, and H. Kanaya, Rock magnetism and magnetic anomalies of the Miyamori Ultramafic Complex, Japan, Butsuri-Tansa (Geophys. Explor.), 46, 269-282, 1993 (in Japanese with English abstract).

Okuma, S., M. Makino, and T. Nakatsuka, Magnetization intensity mapping in and around the Izu-Oshima volcano, Japan, J. Geomag. Geoelectr., 46, 541-556, 1994.

Okuma, S., H. Kanaya, and R. Morijiri, PB-Rock 21, Research Information Database, 87, National Institute of Advanced Industrial Science and Technology (AIST), 2003.

Oshima, S., T. Kondo, T. Tsukamoto, and K. Onodera, Magnetic anomalies at sea around the northern part of Japan, Report of Hydrographic Researches, Hydrographic Office of Japan, 10, 39-44, 1975.

Otofuji, Y., K. Sato, N. Iba, and T. Matsuda, Cenozoic northward translation of the Kitakami massif in northeast Japan: paleomagnetic evidence, Earth Planet. Sci. Lett., 153, 119-132, 1997.

Research Group for Active Faults of Japan, Active faults in Japan: Sheet maps and inventories (revised edition), Univ. of Tokyo Press, Tokyo, 437 pp., 1991 (in Japanese with English abstract).

Sato, H., N. Kato, T. Imaizumi, Y. Ikeda, S. Okada, K. Kagohara, S. Ogino, T. Kawanaka, and K. Kasahara, Seismic reflection profiling across the source fault of the 2003 Northern Miyagi earthquake, NE Japan, Report of a General Research about the earthquake hazard caused by the 2003 Northern Miyagi Earthquake, Project Number: 15800009, Ministry of Education, Culture, Sports, Sciences and Technology, 5-20, 2004 (in Japanese).

Segawa, J. and T. Furuta, Geophysical study of the mafic belts along the margins of the Japanese Islands, Tectonophysics, 44, 1-26, 1978.

Shibata, K., Isotopic ages of granite core from the MITI-Kesennuma Oki Well, Bull. Geol. Surv. Japan, 37, 467-470, 1986.

Takizawa, F., Y. Yanagisawa, K. Kubo, and K. Kamada, Geologic Map of Japan, 1:200,000, Ishinomaki (2nd Ed.), Geol. Surv. Japan, 1992.

Talwani, M., Computation with the help of a digital computer of magnetic anomalies caused by bodies of arbitrary shape, Geophysics, 30, 797$817,1965$.

Tanaka, S. and H. Kanaya, Rock densities in the Kitakami Mountains Part I, Bull. Geol. Surv. Japan, 37, 471-477, 1986 (in Japanese with English abstract).

Tanaka, S. and H. Kanaya, Rock densities in the Kitakami Mountains Part II, Bull. Geol. Surv. Japan, 38, 191-196, 1987 (in Japanese with English abstract).

Umino, N., T. Okada, J. Nakajima, S. Hori, T. Kono, T. Nakayama, N. Uchida, J. Shimizu, J. Suganomata, S. S. N. Gamage, A. Hasegawa, and N. Asano, Hypocenter and focal mechanism distributions of aftershocks of July 262003 M6.4 northern Miyagi, NE Japan, earthquake revealed by temporary seismic observation, Earth Planets Space, 55, 719-730, 2003.

Vacquier, V. and S. Uyeda, Paleomagnetism of nine seamounts in the western Pacific and of three volcanoes in Japan, Bull. Earthq. Res. Inst., 45, 815-848, 1967.

Yokokura, T., K. Yamaguchi, N. Kano, T. Yokota, A. Tanaka, and T. Ohtaki, Seismic reflection surveys around the southern part of hypocentral area of 2003 Miyagi-ken Hokubu earthquake (part 1), Abstracts of the 2004 Japan Earth and Planetary Science Joint Meeting, S053-017, 2004.

S. Okuma (e-mail: s.okuma@aist.go.jp) and H. Kanaya 